\title{
Characterization of urban aerosol in Cork city (Ireland) using aerosol mass spectrometry
}

\author{
M. Dall'Osto ${ }^{1, *}$, J. Ovadnevaite ${ }^{1}$, D. Ceburnis ${ }^{1}$, D. Martin ${ }^{1}$, R. M. Healy ${ }^{2}$, I. P. O'Connor ${ }^{2}$, I. Kourtchev ${ }^{2}$,** $^{\text {, }}$ \\ J. R. Sodeau ${ }^{2}$, J. C. Wenger ${ }^{2}$, and C. O'Dowd ${ }^{1}$ \\ ${ }^{1}$ School of Physics and Centre for Climate and Air Pollution Studies, Ryan Institute, National University of Ireland Galway, \\ Galway, Ireland \\ ${ }^{2}$ Department of Chemistry and Environmental Research Institute, University College Cork, Cork, Ireland \\ * now at: Institute for Environmental Assessment and Water Research (IDAEA-CSIC), Barcelona, Spain \\ ** now at: Department of Chemistry, University of Cambridge, Lensfield Road, Cambridge, UK
}

Correspondence to: M. Dall'Osto (manuel.dallosto@gmail.com)

Received: 31 July 2012 - Published in Atmos. Chem. Phys. Discuss.: 19 November 2012

Revised: 17 April 2013 - Accepted: 18 April 2013 - Published: 15 May 2013

\begin{abstract}
Ambient wintertime background urban aerosol in Cork city, Ireland, was characterized using aerosol mass spectrometry. During the three-week measurement study in 2009 , $93 \%$ of the ca. 1350000 single particles characterized by an Aerosol Time-of-Flight Mass Spectrometer (TSI ATOFMS) were classified into five organic-rich particle types, internally mixed to different proportions with elemental carbon (EC), sulphate and nitrate, while the remaining $7 \%$ was predominantly inorganic in nature. Nonrefractory $\mathrm{PM}_{1}$ aerosol was characterized using a High Resolution Time-of-Flight Aerosol Mass Spectrometer (Aerodyne HR-ToF-AMS) and was also found to comprise organic aerosol as the most abundant species $(62 \%)$, followed by nitrate $(15 \%)$, sulphate $(9 \%)$ and ammonium (9\%), and chloride $(5 \%)$.

Positive matrix factorization (PMF) was applied to the HR-ToF-AMS organic matrix, and a five-factor solution was found to describe the variance in the data well. Specifically, "hydrocarbon-like" organic aerosol (HOA) comprised $20 \%$ of the mass, "low-volatility" oxygenated organic aerosol (LV-OOA) comprised 18\%, "biomass burning" organic aerosol (BBOA) comprised $23 \%$, non-wood solid-fuel combustion "peat and coal" organic aerosol (PCOA) comprised $21 \%$, and finally a species type characterized by primary $\mathrm{m} / \mathrm{z}$ peaks at 41 and 55 , similar to previously reported "cooking" organic aerosol (COA), but possessing different diurnal variations to what would be expected for cooking activities, contributed $18 \%$.
\end{abstract}

Correlations between the different particle types obtained by the two aerosol mass spectrometers are also discussed. Despite wood, coal and peat being minor fuel types used for domestic space heating in urban areas, their relatively low combustion efficiencies result in a significant contribution to $\mathrm{PM}_{1}$ aerosol mass (44\% and $28 \%$ of the total organic aerosol mass and non-refractory total $\mathrm{PM}_{1}$, respectively).

\section{Introduction}

A substantial number of studies have shown a strong relationship between levels of particulate air pollution and a variety of adverse health indicators (Pope and Dockery, 2006; Dockery et al., 1993; Fenger, 1999). Current air quality standards (WHO, 2005) for particulate matter (PM) are based on total mass in a specific size range $\left(\mathrm{PM}_{10}\right.$ or $\left.\mathrm{PM}_{2.5}\right)$, although exposures to particles from different sources may potentially elicit different health effects or exposure-response relationships (Harrison et al., 2000). PM is known to comprise a variety of different chemical components, each with their own sources, behaviours and impacts (Pio et al., 2007). The formulation of cost-effective abatement strategies for atmospheric pollution strongly depends on knowledge of the contributions of individual source categories.

Within the European Union (EU), wide variations in $\mathrm{PM}_{10}$ levels and characteristics can be found. For example, the contribution of mineral dust to all PM size fractions is largest in 
Southern Europe, and the contribution of sea salt to $\mathrm{PM}_{10}$ is largest in Northwestern Europe, while the ratio total carbon $/ \mathrm{PM}_{10}$ is generally largest in Central Europe (Putaud et al., 2010). In the air quality directive (2008/EC/50), the European Commission has set two limit values for $\mathrm{PM}_{10}$ mass concentration for the protection of human health: the daily mean value may not exceed $50 \mu \mathrm{g} \mathrm{m}^{-3}$ more than 35 times in a year and the annual mean value may not exceed $40 \mu \mathrm{g} \mathrm{m}^{-3}$. In Ireland during 2009, all monitoring stations were compliant with this legislation (EPA, 2010). For example, in Cork, a city of about 120000 inhabitants, the average $\mathrm{PM}_{10}$ mass concentration was $18 \pm 10 \mu \mathrm{g} \mathrm{m}^{-3}$ and the daily limit was exceeded only six times. The average $\mathrm{PM}_{2.5}$ concentration at the same monitoring location (Old Station Road, Cork) for the year 2009 was $8 \mu \mathrm{g} \mathrm{m}^{-3}$, but during winter months was found much higher (up to $80 \mu \mathrm{g} \mathrm{m}^{-3}$ ). Previous work revealed that in urban Irish areas, the major components contributing to fine particle mass were, in order of the largest contributions, organic carbon (OC), elemental carbon (EC), and ammonium sulphate/ammonium nitrate (Yin et al., 2005; Ceburnis et al., 2006). More recently, Hellebust et al. (2010) identified shipping, sea salt, crustal material and secondary inorganic aerosols as sources of $\mathrm{PM}_{2.5}$ in Cork city. In a more detailed study, Healy et al. (2010) reported six predominant PM sources: traffic $(23 \%)$, marine $(13 \%)$, long-range transport $(13 \%)$, general combustion $(11 \%)$, domestic combustion $(4.5 \%)$ and shipping (1.5\%); but this study was conducted in August where domestic solid fuel (DSF) burning was at a minimum. By contrast, Kourtchev et al. (2011) reported that DSF burning contributed up to $74.9 \%$ of the measured OC mass concentration during the winter season.

The objective of this study is to characterize the fine PM component detected at an urban background site in Cork using an array of on-line and off-line aerosol techniques in order to improve the source identification of aerosol at very high time resolution in the atmosphere. Two different state-of-the-art on-line aerosol mass spectrometers were deployed: ATOFMS (Aerosol Time-of-Flight Mass Spectrometer) and HR-ToF-AMS (High Resolution Time-of-Flight Aerosol Mass Spectrometer). The ATOFMS provides single particle information on the abundance of different types of aerosol particles as a function of particle size with high time resolution, whereas the AMS quantitatively measures mass concentrations of the non-refractory aerosol components as well as species-resolved size distributions. Whilst the ATOFMS does not have clear source apportionment capabilities due to the difficulties in quantification of its outputs, the AMS has proven itself to be a powerful tool for this purpose (Canagaratna et al., 2007). Additionally, we also used data from off-line filter-based techniques to support the particle types obtained from the statistical analysis of the aerosol mass spectrometry datasets.

\section{Experimental}

\subsection{Location}

The campaign took place from 1-22 February 2009 (all times in this study are in local time - LT) at the Tivoli Industrial Estate and Docks, Cork, Ireland ( $51^{\circ} 54^{\prime} 5 \mathrm{~N}, 8^{\circ} 24^{\prime} 38 \mathrm{~W}$, see Fig. S1 in the Supplement). A detailed description of the site is given elsewhere (Healy et al., 2009; Hellebust et al., 2010). Briefly, the site is located in the Port of Cork, approximately $3 \mathrm{~km}$ east of Cork city centre. Shipping berths are located $400-600 \mathrm{~m}$ to the southwest, while the main road carrying traffic east out of the city and towards Dublin lies $200 \mathrm{~m}$ to the north of the site. Residential areas immediately surround the site on all sides except the north and northeast. Air quality data from the monitoring station in the city centre (Old Station Road, $3 \mathrm{~km}$ from the monitoring site) were also used in order to compare them with the data obtained in this study.

\subsection{Off-line aerosol techniques}

$\mathrm{PM}_{2.5}$ aerosol samples were collected on Pallflex Tissue quartz fibre filters $(150 \mathrm{~mm}$ diameter, pre-fired for $24 \mathrm{~h}$ at $580^{\circ} \mathrm{C}$ ) using a high-volume (Digitel) sampler with a flow rate of $500 \mathrm{~L} \mathrm{~min}^{-1}$. The sampling was conducted from 2 to 22 February 2009 at $6 \mathrm{~h}$ resolution. The filters were extracted and analysed by gas chromatography/mass spectrometry (GC/MS) as described in Kourtchev et al. (2011). Briefly, a part of the quartz fibre filter, $6-12 \mathrm{~cm}^{2}$ depending on the OC loading, was spiked with $0.5 \mu \mathrm{g}$ of the internal recovery standard methyl- $\beta$-D-xylanopyranoside (MXP) and left to dry for $30 \mathrm{~min}$ before being extracted three times with $20 \mathrm{~mL}$ of dichloromethane-methanol $(80: 20$, $\mathrm{v} / \mathrm{v}$ ) under ultrasonic agitation for $30 \mathrm{~min}$. The filtrates were combined, reduced to approximately $1 \mathrm{~mL}$ with rotary evaporation at $35^{\circ} \mathrm{C}$ and filtered through a Teflon filter $(0.45 \mu \mathrm{m})$. The filtrate was transferred to a $2 \mathrm{~mL}$ glass vial and evaporated to dryness under a gentle stream of nitrogen. The residue was derivatized by the addition of $50 \mu \mathrm{L}$ of N,O-bis(trimethylsilyl)trifluoroacetamide containing $1 \%$ trimethylchlorosilane (BSTFA+1\% TMCS) and $30 \mu \mathrm{L}$ pyridine, and heated at $70^{\circ} \mathrm{C}$ for $1 \mathrm{~h}$. After cooling to room temperature, an aliquot of $1 \mu \mathrm{L}$ was analysed by GC/MS in electron ionization (EI) mode.

The employed GC/MS method was optimized for determination of polar organic compounds that are markers for fungal spores, isoprene, $\alpha-, \beta$-pinene oxidation products, and biomass burning. During the winter period, only biomass burning compounds, i.e. levoglucosan, galactosan and mannosan, were detected and quantified. The concentrations, time trends and contribution of these polar compounds to the OC are reported in Kourtchev et al. (2011). Furthermore, $\mathrm{PM}_{2.5}$ aerosol samples were also chemically characterized for water-soluble species. Chemical analysis of inorganic content in the $\mathrm{PM}_{2.5}$ fraction employed ion chromatography 
(Dionex ICS-2000) providing concentrations for fluoride, chloride, bromide, nitrate and sulphate.

\subsection{On-line aerosol techniques}

A TEOM (tapered element oscillating microbalance, Thermo Electron model 1400a) was deployed on-site for the measurement of $\mathrm{PM}_{2.5}$ mass concentrations. The TEOM data were scaled with collocated gravimetric measurements during the field study. $\mathrm{PM}_{2.5}$ and $\mathrm{PM}_{10}$ data were also available from the monitoring station at Old Station Road in Cork city centre (EPA, 2009). EC and OC mass concentrations were measured using a thermal-optical carbon aerosol analysis instrument (Sunset Laboratory Inc., field model 3rd generation) fitted with a $\mathrm{PM}_{2.5}$ cyclone. The system uses a modified version of the National Institute for Occupational Safety and Health (NIOSH) 5040 thermal-optical protocol during analysis, to provide time-resolved OC/EC splits on a semi-real-time basis.

The ATOFMS (Model 3800-100, TSI, Inc.) was used to measure bipolar mass spectra of individual aerosol particles (Gard et al., 1997). Ambient aerosol is focused into a narrow particle beam in the aerodynamic lens. Using a 2-laser velocimeter, particle sizes are determined from particle velocity after acceleration into the vacuum, providing - with appropriate ATOFMS size calibration - a size range of 0.1 to $3 \mathrm{mi}-$ crometers (Gard et al., 1997). In addition, the light scattered by the particles is used to trigger a pulsed high-power desorption and ionization laser $\left(\lambda=266 \mathrm{~nm}, \approx 1 \mathrm{~mJ}_{\text {pulse }}{ }^{-1}\right)$ which evaporates and ionizes the particle in the centre of the ion source of a bipolar reflectron ToF-MS $(\mathrm{m} / \Delta \mathrm{m} 600)$. Thus, a positive and negative ion mass spectrum are obtained for each single particle.

The HR-ToF-AMS focuses particles in the size range 50$600 \mathrm{~nm}$ onto a hot surface (about $600^{\circ} \mathrm{C}$ ) using an aerodynamic lens assembly (De Carlo et al., 2006). Non-refractory particle components flash-evaporate on the hot surface; the evolving vapour is electron impact $(70 \mathrm{eV})$ ionized, and the ions are transported into an orthogonal extraction ToFMS for high-resolution mass analysis. The HR-ToF-AMS was deployed in the standard configuration, taking both mass spectrum (MS) and particle time-of-flight (pToF) data. The instrument was alternatively run in "V-mode" (with a mass resolution of up to $3000 \mathrm{~m} / \Delta \mathrm{m}$ ) and "W-mode" by using a second reflectron, which increases resolution to 6000 $\mathrm{m} / \Delta \mathrm{m}$ but decreases sensitivity by approximately one order of magnitude. Standard ionization efficiency and size calibrations were performed during the campaign, including particle time-of-flight calibration to convert the particle flight times into particle diameters and to determine the instrument background parameters by measurements through a high-efficiency particulate air filter (HEPA filter) during the campaign (De Carlo et al., 2006). The mass spectrometers utilized the same sample inlet fitted with a $\mathrm{PM}_{2.5}$ cyclone, situated on the roof of the trailer containing the instruments, at a height of about $4 \mathrm{~m}$ above ground. A quarter-inch internal diameter stainless steel tube led inside the trailer to a manifold. From there the sample air was dried before arriving to the instruments, efficiently sampling particles at sizes below the cyclone $\mathrm{PM}_{2.5}$ cut-offs.

\subsubsection{Mass spectrometers' data processing}

\section{ATOFMS}

The ATOFMS collected about 1350000 single particle positive and negative mass spectra. The TSI ATOFMS dataset was imported into YAADA (Yet Another ATOFMS Data Analyzer) and single particle mass spectra were clustered with Adaptive resonance theory neural network, ART-2a (Song et al., 1999). The parameters used for ART-2a were learning rate 0.05 , vigilance factor 0.85 , and iterations 20 . Similar clusters obtained by ART-2a were manually merged (Dall'Osto and Harrison, 2006) so that the total number of clusters describing the whole dataset was reduced to ten.

\section{HR-ToF-AMS}

Mass concentrations and size distributions of the aerosol species measured with the HR-ToF-AMS were calculated using the methods outlined by DeCarlo et al. (2006). Standard ToF-AMS data analysis software packages (SQUIRREL v1.49 and PIKA v1.08) were used. For mass concentration calculations, an empirical particle collection efficiency (CE) factor of 0.5 was used, already widely found to be representative for ambient particles in many AMS studies (Jayne et al., 2000; Canagaratna et al., 2007), and the value of 0.5 was further validated by good inter-comparison with off-line ion mass concentration measurements obtained in this study (see Sect. 3.4.1). The HR-ToF-AMS organic matrix was analysed by positive matrix factorization (PMF), a bilinear unmixing model that identifies factors which serve to approximately reconstruct the measured organic mass spectra for each point in time (Ulbrich et al., 2009). Each factor is comprised of a (constant) mass spectrum and a time series of mass concentration, and all values in the factors are constrained to be positive. The model is solved by minimizing the sum of the weighed squared residuals of the fit (known as Q). The PMF model was solved with the PMF2.exe algorithm v.4.2 using as inputs the high-resolution OA mass spectral matrix and associated error matrix (Paatero and Tapper, 1994).

\subsection{Other techniques}

A suite of real-time gas analysers was located at the site for the duration of the campaign: $\mathrm{SO}_{2}, \mathrm{NO} / \mathrm{NO}_{\mathrm{x}}$ and $\mathrm{O}_{3}$ were monitored using Thermo Electron models 43i, 5020 SPA, 42i and $49 \mathrm{i}$, respectively. Wind speed, wind direction, temperature, humidity and rainfall were monitored using a Casella NOMAD weather station deployed on the monitoring site. 
Meteorological data were also obtained from the monitoring stations in the city centre, Port of Cork and Cork Airport. The meteorological data overall compared well, but the most complete and reliable set of measurements were found to be from Cork Airport and were used in this study.

\subsection{Peat and coal burning experiment}

In order to facilitate the quantification of the relative contribution of different domestic fuel sources to ambient $\mathrm{PM}_{1}$ levels, a series of controlled experiments were undertaken to obtain mass spectra of peat and coal combustion. A controlled combustion experiment for each of the fuel types was performed, with each fuel burned for approximately $40 \mathrm{~min}$ in an outdoor grate and with fresh combustion particles introduced into the HR-ToF-AMS. The grate was open to ambient air without temperature control. The ambient conditions represented very clean air masses, as indicated by the following mass concentrations (in $\mu \mathrm{g} \mathrm{m}^{-3}$ ) observed by AMS: organic aerosol $\sim 0.3, \mathrm{NO}_{3}^{-} \sim 0.02, \mathrm{SO}_{4}^{2-} \sim 0.8$ and $\mathrm{NH}_{4}^{+} \sim 0.3$. The coal used was smokeless coal, which is a legal prerequisite for burning coal in Cork city as it is a designated smokeless fuel zone. Emissions were diluted to $\sim 30 \mu \mathrm{g} \mathrm{m}^{-3}$ with filtered ambient air. Peat, which is used extensively in Ireland for domestic space heating, was obtained locally, and concentrations were repeated twice with very similar results; therefore, the mass spectra maintained $\sim 100 \mu \mathrm{g} \mathrm{m}^{-3}$. All experiments were presented in this study represent the $m / z$ averages over the both experiments.

\section{Results}

\subsection{Meteorology}

The air mass back trajectories were calculated using HYSPLIT (Draxler and Rolph, 2003) analysis. The results are presented in Table S1, where the sampling days were classified as continental-marine Polar ( $\mathrm{cm} P, 6$ days), continental Po$\operatorname{lar}(c P, 2$ days), marine Arctic ( $m A, 4$ days) and marine Po$\operatorname{lar}(m P, 10$ days). Taking the approach of Rimetz-Planchon (2008) - investigating $\mathrm{PM}_{10}$ pollution episodes associated with meteorological situations in an urban and industrialized coastal site of the southern part of the North Sea - and by considering both air mass back trajectories and local meteorology, two different scenarios of seven days each were identified: stagnant air mass conditions (days 1-3 and 16-19 February, named "stagnant" period, Period S.) and cold marine air mass (consecutive days: 5-11 February, named "marine" period, Period M.). It should be noted that the temporal trend of sea spray ATOFMS particle type (see Sect. 3.3) was also used to validate the two different scenarios. It should be noted that air arriving from the Atlantic Ocean will in many cases have traversed part of Ireland and therefore collected pollution to some degree before reaching the site. However, the main significance of $m P$ air masses is that they are faster moving and therefore cause enhanced dilution of local pollutants. Period M. is characterized by colder Atlantic air masses $\left(2.7 \pm 2{ }^{\circ} \mathrm{C}\right)$ and stronger winds $\left(4.9 \pm 2 \mathrm{~m} \mathrm{~s}^{-1}\right)$ relative to Period S. $\left(4.9 \pm 3^{\circ} \mathrm{C}\right.$ and $3.7 \pm 2 \mathrm{~m} \mathrm{~s}^{-1}$, respectively, Fig. S3 and Table 1a). Figure 1a shows the diurnal profiles for the relative humidity $(\mathrm{RH})$ and temperature $(T)$. The Period M. scenario presents a stronger day-night variation period $\left(4.3^{\circ} \mathrm{C}\right)$ relative to Period S. $\left(1.9^{\circ} \mathrm{C}\right)$.

\subsection{Air quality parameters: PM and gaseous concentrations}

$\mathrm{PM}_{10}$ mass concentration limit values were not exceeded in the city of Cork during the field study, with a daily average mean value $\mathrm{PM}_{10}$ of $24 \pm 10 \mu \mathrm{g} \mathrm{m}^{-3}$ (Table 1c). During Period S., levels of PM (both $\mathrm{PM}_{2.5}$ and $\mathrm{PM}_{10}$ ) and nitrogen gaseous pollutants were higher than during Period M., likely due to the low average wind speed (Table 1b, c). The mass concentration of $\mathrm{PM}_{2.5}$ at the port was on average $4.1 \mu \mathrm{g} \mathrm{m}^{-3}$ lower than at the city centre site. However, Fig. S2 shows higher $\mathrm{PM}_{2.5}$ values at the port on 4, 6, 11, and 18 February, due to enhanced specific local emissions (see Sect. 3.3). Gaseous concentrations for $\mathrm{NO}$ and $\mathrm{NO}_{2}$ were $19 \pm 6 \mu \mathrm{g} \mathrm{m}^{-3}$ and $18 \pm 6 \mu \mathrm{g} \mathrm{m}^{-3}$ and presented maximum values, as well as the ratio EC / OC $\left(0.37 \pm 0.2 \mu \mathrm{g} \mathrm{m}^{-3}\right)$, during traffic rush hours (see Fig. 1b, data are averages for the entire study period). Ozone values (average for all field study, $9 \pm 5 \mu \mathrm{g} \mathrm{m}^{-3}$ ) were found to moderately increase between 11:00 and 16:00 (local time), due to the limited photochemical activity encountered during colder months in the Northern European latitudes. $\mathrm{SO}_{2}$ concentrations were generally low $\left(1.74 \pm 0.4 \mu \mathrm{g} \mathrm{m}^{-3}\right)$. However, seven spikes of elevated $\mathrm{SO}_{2}$ concentrations (hourly values of 3-6 $\mu \mathrm{g} \mathrm{m}^{-3}$ ) were detected during the field study, which were associated with a specific particle type detected with the aerosol mass spectrometers and thus attributed to local ship emissions as discussed in Sect. 4.2.

\subsection{Single particle mass spectrometry analysis}

The ATOFMS dataset was reduced to ten different particle types, further reduced to four more generic categories as summarized in Table 2: organic, inorganic, spikes and nitrate-chloride. Organic particles represented $93 \%$ of the total number of particles classified, whereas inorganic particles represented less than $4 \%$ of the sample. Ship emissions were defined by the strong vanadium signature (Pastor et al., 2003), whereas "spikes" were defined as ATOFMS particle types peaking for short periods of time and attributed to local PM sources. Nitrate-chloride (2.7\% of the total classified) presented only negative ion mass spectra, and will be the subject of future publications. The average mass spectra of the ten specific particle types are shown in Fig. 2 and further details are described below: 

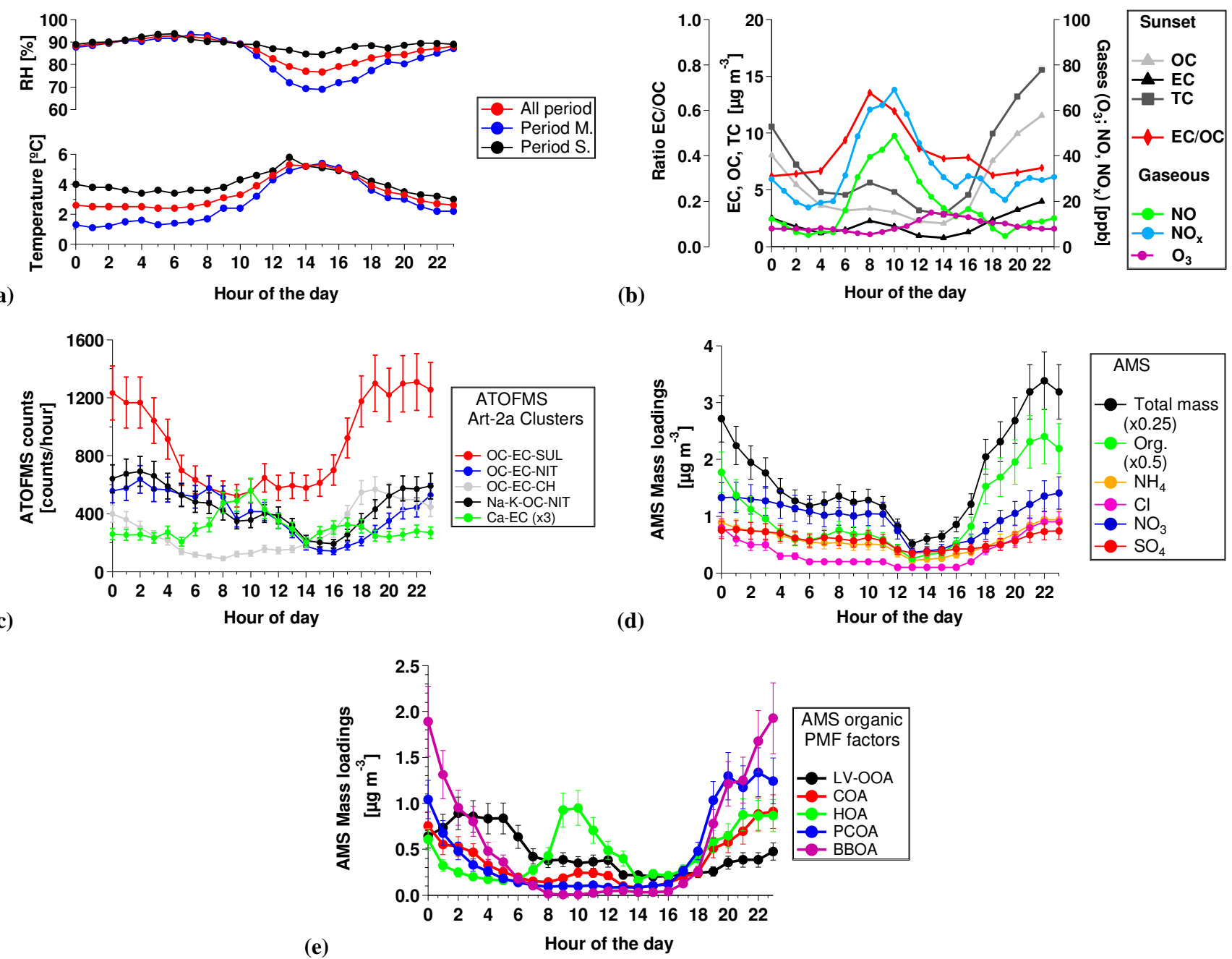

Fig. 1. Diurnal profiles of (a) temperature and RH, (b) sunset and gaseous measurements, (c) ATOFMS main particle types, (d) AMS mass loadings and (e) AMS PMF factors.

- OC-EC-SUL (organic carbon - elemental carbon - sulphate; $37.8 \%$ ). Figure $2 \mathrm{a}$ shows an average positive mass spectrum with peaks due to $\mathrm{OC}(\mathrm{m} / \mathrm{z} 27,37,43$, $50)$ and $\mathrm{EC}(\mathrm{m} / \mathrm{z} 12,36,48,60)$ and negative spectra dominated by sulphate $(\mathrm{m} / \mathrm{z}-97)$ (Dall'Osto and Harrison, 2006). This cluster was found to comprise the strongest sulphate signature, with a size distribution centred at $250 \mathrm{~nm}$ diameter and a diurnal trend (Fig. 1c) peaking during the evening (19:00-23:00), pointing towards a domestic combustion source.

- OC-EC-NIT (organic carbon - elemental carbon - nitrate; $9.4 \%$ ). Figure $2 \mathrm{~b}$ shows a positive mass spectrum similar to OC-EC-SUL, but a stronger signal due to nitrate $(\mathrm{m} / \mathrm{z}-46$ and -62$)$ is observed in the negative spectrum. This particle type presented a larger size distribution occurring at $400 \mathrm{~nm}$ and, in contrast with the OC-EC-SUL temporal trend, exhibits a later nighttime peak (Fig. 1c). This particle type can be attributed to the condensation of nitrate on existing aerosols caused by nighttime boundary layer dynamics.

- OC-EC-CH (organic carbon - elemental carbon - hydrocarbon rich; $22.6 \%$ ). This particle type, internally mixed with both nitrate and sulphate, contained a unique feature in terms of high $\mathrm{C}_{\mathrm{x}} \mathrm{H}_{\mathrm{y}}$ peaks with $\mathrm{m} / z 37$ $\left(\left[\mathrm{C}_{3} \mathrm{H}\right]^{+}\right)$representing the strongest base peak (Fig. 2c). The negative spectrum also displays characteristic peaks of primary hydrocarbon species $(\mathrm{m} / \mathrm{z}$ peaks including $-24,-25$ and $\left.-26 ;\left[\mathrm{C}_{\mathrm{x}} \mathrm{H}_{\mathrm{y}}\right]^{-}\right)$. Additionally, less secondary species can be found in this particle type relative to the previous two (Fig. 2a, b). Cluster OC-EC$\mathrm{CH}$ was found to possess an aerosol number size distribution at around $250 \mathrm{~nm}$, and a diurnal profile (Fig. 1c) similar to that associated with OC-EC-SUL, albeit more pronounced during the period from 19:00 to 21:00, also pointing to a local combustion source. 
Table 1. Averages ( \pm 1 standard deviation) for entire field study and for the two selected temporal periods (S. and M.) of (a) meteorological parameters, (b) gaseous concentrations, (c) particulate mass, (d) Sunset instrument, (e) AMS aerosol mass loadings, (f) AMS PMF organic factors and (g) ATOFMS ART-2a particle types.

\begin{tabular}{|c|c|c|c|c|c|}
\hline Class & Parameters & ALL & Period S. (Stagnant) & Period M. (Marine) & Ratio periods S/M \\
\hline \multirow{5}{*}{$\begin{array}{l}\text { (a) Meteorological } \\
\text { parameters }\end{array}$} & Temp $\left({ }^{\circ} \mathrm{C}\right)$ & $4 \pm 3$ & $4.9 \pm 3$ & $2.7 \pm 2$ & 1.5 \\
\hline & $\mathrm{RH}(\%)$ & $87 \pm 9$ & $89 \pm 8$ & $83 \pm 10$ & 1.1 \\
\hline & $\mathrm{WS}\left(\mathrm{m} \mathrm{s}^{-1}\right)$ & $4 \pm 2$ & $3.7 \pm 2$ & $4.9 \pm 2$ & 0.7 \\
\hline & Pressure (bar) & $1015 \pm 15$ & $1018 \pm 15$ & $1003 \pm 9$ & 1 \\
\hline & Rain $(\mathrm{mm})$ & $0.025 \pm 0.2$ & $0.06 \pm 0.2$ & $0.03 \pm 0.1$ & 2 \\
\hline \multirow{4}{*}{$\begin{array}{l}\text { (b) Gaseous } \\
\text { concentrations } \\
\left(\mu \mathrm{g} \mathrm{m}^{-3}\right)\end{array}$} & $\mathrm{SO}_{2}$ & $1.74 \pm 0.4$ & $1.94 \pm 0.4$ & $1.60 \pm 0.3$ & 1.2 \\
\hline & $\mathrm{NO}$ & $19 \pm 6$ & $20 \pm 27$ & $13 \pm 25$ & 1.4 \\
\hline & $\mathrm{NO}_{2}$ & $18 \pm 6$ & $19 \pm 10$ & $12 \pm 25$ & 1.4 \\
\hline & $\mathrm{O}_{3}$ & $9 \pm 5$ & $8 \pm 5$ & $11 \pm 6$ & 0.7 \\
\hline \multirow{3}{*}{$\begin{array}{l}\text { (c) Particulate } \\
\text { mass } \\
\left(\mu \mathrm{g} \mathrm{m}^{-3}\right)\end{array}$} & $\mathrm{PM}_{2.5}$ port & $13 \pm 7$ & $14 \pm 7$ & $12 \pm 6$ & 1.2 \\
\hline & $\mathrm{PM}_{2.5}$ city & $16 \pm 8$ & $18 \pm 6$ & $14 \pm 5$ & 1.2 \\
\hline & $\mathrm{PM}_{10}$ city & $24 \pm 14$ & $27 \pm 9$ & $22 \pm 6$ & 1.2 \\
\hline (d) Sunset & $\mathrm{EC}$ & $1.99 \pm 1$ & $1.9 \pm 1$ & $1.7 \pm 1$ & 1.1 \\
\hline OC\&EC mass & $\mathrm{OC}$ & $5.3 \pm 2$ & $5.1 \pm 2$ & $4 \pm 2$ & 1.2 \\
\hline loadings & $\mathrm{TC}$ & $7.3 \pm 3$ & $7.0 \pm 3$ & $5.7 \pm 1$ & 1.1 \\
\hline$\left(\mu \mathrm{g} \mathrm{m}^{-3}\right)$ & $\mathrm{EC} / \mathrm{OC}$ & $0.37 \pm 0.2$ & $0.37 \pm 0.2$ & $0.43 \pm 0.25$ & 0.8 \\
\hline \multirow{5}{*}{$\begin{array}{l}\text { (e) AMS } \\
\text { mass } \\
\text { loadings } \\
\left(\mu \mathrm{g} \mathrm{m}^{-3}\right)\end{array}$} & AMS org. & $4.3 \pm 2(62 \%)$ & $4.7 \pm 2(57 \%)$ & $3.4 \pm 2(70 \%)$ & 1.4 \\
\hline & AMS nit. & $1.0 \pm 0.5(15 \%)$ & $1.2 \pm 0.5(15 \%)$ & $0.6 \pm 0.3(12 \%)$ & 1.9 \\
\hline & AMS sul. & $0.6 \pm 0.2(9 \%)$ & $1.0 \pm 0.3(12 \%)$ & $0.3 \pm 0.3(7 \%)$ & 3.5 \\
\hline & AMS amm. & $0.6 \pm 0.3(9 \%)$ & $0.8 \pm 0.3(10 \%)$ & $0.3 \pm 0.2(7 \%)$ & 2.4 \\
\hline & AMS chl. & $0.4 \pm 0.2(5 \%)$ & $0.5 \pm 0.1(6 \%)$ & $0.2 \pm 0.1(6 \%)$ & 2.0 \\
\hline \multirow{5}{*}{$\begin{array}{l}\text { (f) AMS PMF } \\
\text { organic } \\
\text { factor } \\
\left(\mu \mathrm{g} \mathrm{m}^{-3}\right)\end{array}$} & LV-OOA & $0.78 \pm 0.4(18 \%)$ & $1.12 \pm 0.3(23 \%)$ & $0.38 \pm 0.3(11 \%)$ & 2.9 \\
\hline & $\mathrm{COA}$ & $0.76 \pm 0.3(18 \%)$ & $0.87 \pm 0.5(18 \%)$ & $0.50 \pm 0.3(15 \%)$ & 1.7 \\
\hline & HOA & $0.84 \pm 0.4(20 \%)$ & $0.97 \pm 0.3(20 \%)$ & $0.77 \pm 0.3(23 \%)$ & 1.2 \\
\hline & PCOA & $0.92 \pm 0.3(21 \%)$ & $0.77 \pm 0.5(16 \%)$ & $1.09 \pm 0.4(32 \%)$ & 0.7 \\
\hline & BBOA & $0.98 \pm 0.4(23 \%)$ & $1.13 \pm 0.5(23 \%)$ & $0.63 \pm 0.3(19 \%)$ & 1.8 \\
\hline \multirow{7}{*}{$\begin{array}{l}\text { (g) ATOFMS } \\
\text { ART-2a } \\
\text { particle } \\
\text { types } \\
\text { (count/hour) }\end{array}$} & OC-EC-SUL & $1009 \pm 394$ & $849 \pm 300$ & $1154 \pm 343$ & 0.7 \\
\hline & OC-EC-NIT & $432 \pm 231$ & $414 \pm 230$ & $349 \pm 138$ & 1.2 \\
\hline & OC-EC-CH & $611 \pm 269$ & $364 \pm 124$ & $1007 \pm 265$ & 0.4 \\
\hline & V-NIT & $18 \pm 7$ & $31 \pm 21$ & $6 \pm 3$ & 5.3 \\
\hline & Na-K-OC-EC & $316 \pm 88$ & $310 \pm 129$ & $245 \pm 187$ & 1.3 \\
\hline & Ca-EC & $124 \pm 56$ & $112 \pm 87$ & $126 \pm 67$ & 0.9 \\
\hline & $\mathrm{NaCl}$ & $81 \pm 41$ & $43 \pm 32$ & $138 \pm 87$ & 0.3 \\
\hline
\end{tabular}

- Ca-EC (calcium - elemental carbon; 4.8\%) The positive ion mass spectrum of Fig. $2 \mathrm{~d}$ shows a strong peak at $m / z 40\left([\mathrm{Ca}]^{+}\right)$, and EC peaks $(\mathrm{m} / \mathrm{z}, 12,24,36,48$, 60) are also observed in both positive and negative mass spectra. This particle type was only detected in the lower size range of the ATOFMS (ca. $150 \mathrm{~nm}$ ), was found to spike during morning rush hour times (Fig. 1c) and is attributed to lubricating oil from traffic emissions (Spencer et al., 2006; Drewnick et al., 2008).

- Na-K-OC-NIT (sodium - potassium - organic carbon nitrate; $17.9 \%$ ). This particle type (Fig. 2e) was found internally mixed with both inorganic species, such as sodium $(m / z, 23)$ and potassium $(m / z \quad 39)$, and OC $(\mathrm{m} / \mathrm{z} 12,27,36,37,43,50)$. It contains less intense EC peaks relative to the other ATOFMS particle types (Fig. 2a, b, c) and a size distribution peak centred at about $400 \mathrm{~nm}$. The diurnal profile of this particle type is very similar to the other nitrate-rich particle type presented (OC-EC-NIT), and is strongly enhanced during nighttime hours (Fig. 1c). It is likely these two particle types are nitrate-containing particles with different inorganic-organic mixing state.

- $\mathrm{NaCl}$ (sodium chloride; $3.0 \%$ ). Figure 2f shows peaks at $m / z \quad 23\left([\mathrm{Na}]^{+}\right), m / z \quad 81\left(\left[\mathrm{Na}_{2} \mathrm{Cl}\right]^{+}\right)$and nitrate $(\mathrm{m} / z-46$ and $\mathrm{m} / z-62)$. This feature is typical of ATOFMS mass spectra representative of sea salt 
Table 2. ATOFMS particle types.

\begin{tabular}{|c|c|c|c|c|}
\hline General ATOFMS & ATOFMS cluster & Possible source attribution & $\mathrm{N}$ particle & $\%$ \\
\hline \multirow{5}{*}{ Organic } & OC-EC-SUL & Domestic fuel combusion & 505096 & 37.8 \\
\hline & OC-EC-CH & Domestic fuel combusion (peat) & 302445 & 22.6 \\
\hline & OC-EC-NIT & Secondary aerosol internally mixed with EC & 132985 & 9.4 \\
\hline & Na-K-OC-NIT & Secondary aerosol internally mixed with EC & 155202 & 17.9 \\
\hline & Ca-EC & Traffic & 64681 & 4.8 \\
\hline \multirow{3}{*}{ Inorganic } & $\mathrm{NaCl}$ & Sea salt & 40445 & 3.0 \\
\hline & V-NIT & Shipping & 9228 & 0.7 \\
\hline & V-K-SUL & Shipping & 2411 & 0.2 \\
\hline \multirow{2}{*}{ Spikes } & Ca-dust & Road dust & 1984 & 0.1 \\
\hline & EC-POS & Local combustion & 607 & 0.04 \\
\hline Nitrate-chloride & Negative spectrum only & Unknown & 36538 & 2.7 \\
\hline Unclassified & Unclassified & Unclassified & 84322 & 6.3 \\
\hline TOTAL & & & 1335944 & 100.0 \\
\hline
\end{tabular}

particles internally mixed with nitrate (Dall'Osto et al., 2004), and these particles exhibit the largest size mode of all the ATOFMS particle types $(>1 \mu \mathrm{m})$.

- Ca-Dust (calcium-dust; $0.1 \%$ ). Figure $2 \mathrm{~g}$ shows peaks due to $\mathrm{Na}(\mathrm{m} / \mathrm{z}, 23), \mathrm{Ca}(\mathrm{m} / \mathrm{z} 40), \mathrm{Fe}(\mathrm{m} / \mathrm{z}, 56), \mathrm{Cl}$ $(\mathrm{m} / \mathrm{z},-35)$ and nitrate $(\mathrm{m} / \mathrm{z}-62)$. This particle type also exhibits a coarse mode ( $>1$ mum), was observed during short events on 4, 9, 11 and 18 February, mainly during morning times, and is likely to be due to resuspension of dust (Guazzotti et al., 2003).

- EC-POS (elemental carbon - phosphate; $0.1 \%$ ). Figure $2 \mathrm{~h}$ shows EC signals $(\mathrm{m} / \mathrm{z}, 12,36,60)$ in the positive mass spectrum and a strong peak at $\mathrm{m} / \mathrm{z} 79$ due to phosphate $\left(\left[\mathrm{PO}_{3}\right]^{-}\right)$in the negative spectrum. This particle type presented a size distribution mode in the finest ATOFMS fraction at about $200 \mathrm{~nm}$, and has previously been attributed to lubricating oil from vehicles (Spencer et al., 2006). It was found to spike on 10, 14 and 20 February, mainly during morning times, and is attributed to highly localized vehicle emissions. Whilst cluster Ca-EC was found to be associated with traffic emissions in this study (see diurnal profile on Fig. 1c), the EC-POS type was found to be more localized, likely due to a nearby anthropogenic combustion source, e.g. a generator or passing truck.

- V-NIT (vanadium-nitrate; $0.7 \%$ ). Figure 2i shows the positive mass spectrum with a strong vanadium signature $\left(\mathrm{m} / z, 51[\mathrm{~V}]^{+}\right.$and $\left.67[\mathrm{VO}]^{+}\right)$and minor peaks due to carbon $(\mathrm{m} / \mathrm{z} 12), \mathrm{K}(\mathrm{m} / \mathrm{z} 39)$ and $\mathrm{Fe}(\mathrm{m} / \mathrm{z}, 56)$. The negative mass spectrum shows mainly nitrate $(\mathrm{m} / \mathrm{z}-46$ and -62$)$, and, to a lesser extent, sulphate $(\mathrm{m} / \mathrm{z}-97)$. This particle type was found mainly during Period S. and with a size distribution peak at about $400 \mathrm{~nm}$. We attribute this particle type to aged ship emissions/oil com- bustion particles (Pastor et al., 2003; Dall'Osto and Harrison, 2006).

- V-K-SUL (vanadium-potassium-sulphate; $0.2 \%$ ). Figure $2 \mathrm{j}$ shows a vanadium-rich particle type internally mixed with potassium $(\mathrm{m} / \mathrm{z}$ 39) and sulphate $(\mathrm{m} / \mathrm{z}-97)$. Relative to the other V-rich particle type (V-NIT), it presents a much smaller characteristic size range $(250 \mathrm{~nm})$, and its correlation with $\mathrm{SO}_{2}$ spikes points to fresh ship emissions. A more in-depth discussion of Vrich particles can be found in Sect. 4.2.1.

Whilst the AMS has a well-proven capability to quantify generic source-related categories of non-refractory aerosol, the ATOFMS gives mass spectral information for individual particles. Even after clustering particles with similar size distribution and mass spectral characteristics, the ATOFMS presents information which can be very difficult to interpret in relation to sources or atmospheric processing (Dall'Osto and Harrison, 2012). The ATOFMS cannot provide quantitative aerosol mass loading concentrations, but its unique strength lies in the fact that it can monitor, in real time, variations in the single particle composition (see the temporal trends presented in Fig. 3). Only some of the correlations between the ATOFMS particle types detected in this study and other measurements (HR-ToF-AMS, off-line techniques, gas measurements) were found to be statistically valid. As expected, Ca-EC correlated with $\mathrm{NO}\left(R^{2}=0.7\right)$ and $\mathrm{NO}_{\mathrm{x}}\left(R^{2}=0.65\right)$, Na-NIT correlated with nitrate $\left(R^{2}=0.55\right)$ and sulphate $\left(R^{2}=0.50\right)$, while the only particle type that correlated with levoglucosan was EC-OC-SUL $\left(R^{2}=0.45\right)$. Further correlations between ATOFMS particle types and organic particle types obtained by PMF analysis of the HRToF-AMS data are discussed in Sect. 4.4.

In this study ATOFMS particle types $\mathrm{NaCl}$, V-rich particles and $\mathrm{Ca}-\mathrm{EC}$ can be attributed to sea spray, ship and 


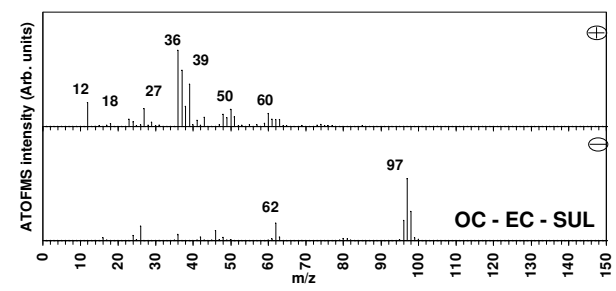

(a)

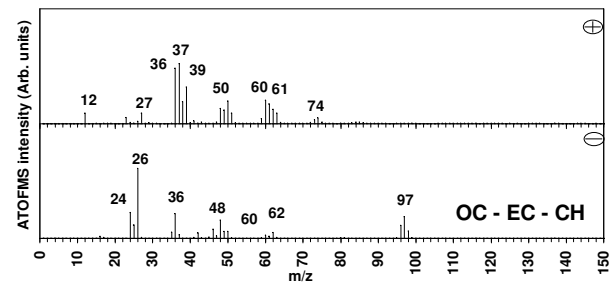

(c)

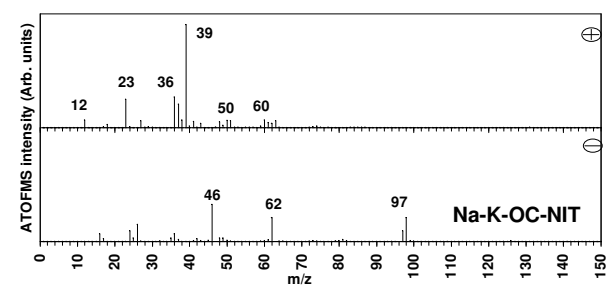

(e)

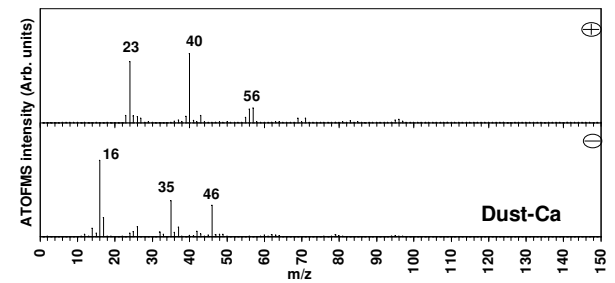

(g)

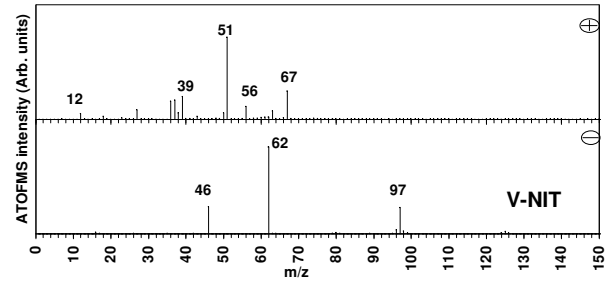

(i)

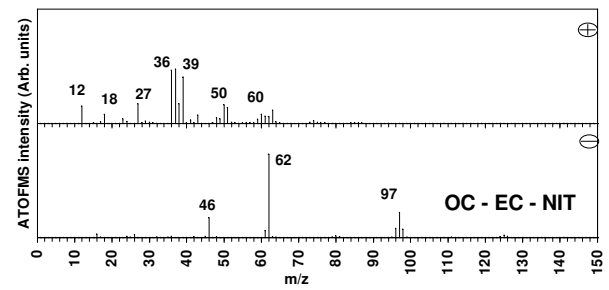

(b)

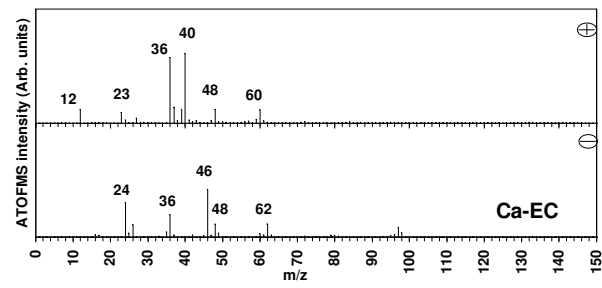

(d)

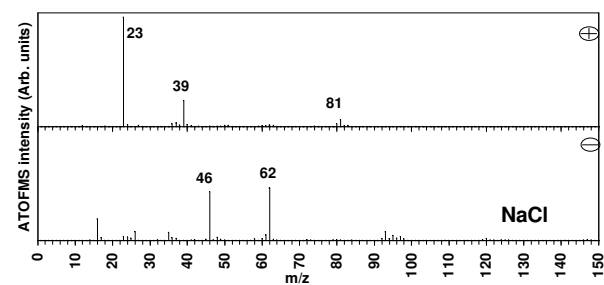

(f)

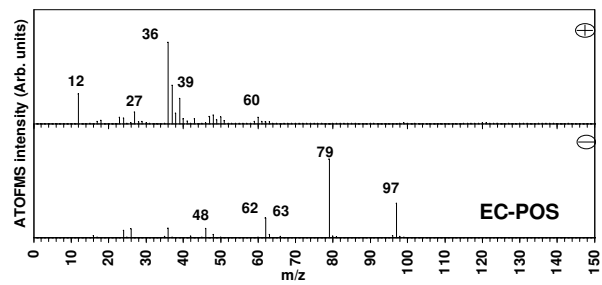

(h)

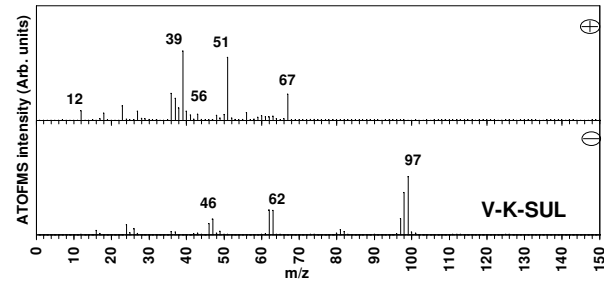

(j)

Fig. 2. (a-j): ATOFMS ART-2a results for the ten particle types (absolute values).

vehicular traffic emissions, respectively. By contrast, it is more difficult to attribute the ATOFMS particle types to specific space heating aerosol sources. A number of ATOFMS studies have previously reported biomass burning particles in ambient air (Pastor et al., 2003; Moffet et al., 2008). Healy et al. (2010) also reported ATOFMS average mass spectral signatures for coal, peat and wood combustion by measur- ing fresh combustion particles emitted from an outdoor stove. Broadly, peat particles were rich in sodium and hydrocarbonlike species; coal particles were found to have the strongest sulphate signature and the lowest metallic content; and wood positive ATOFMS ion mass spectra were found to be dominated by potassium ions $\left(\mathrm{m} / z, 39[\mathrm{~K}]^{+}\right.$and $\left.\mathrm{m} / z, 113\left[\mathrm{~K}_{2} \mathrm{Cl}\right]^{+}\right)$. Among common peaks attributed to EC and OC (usually 


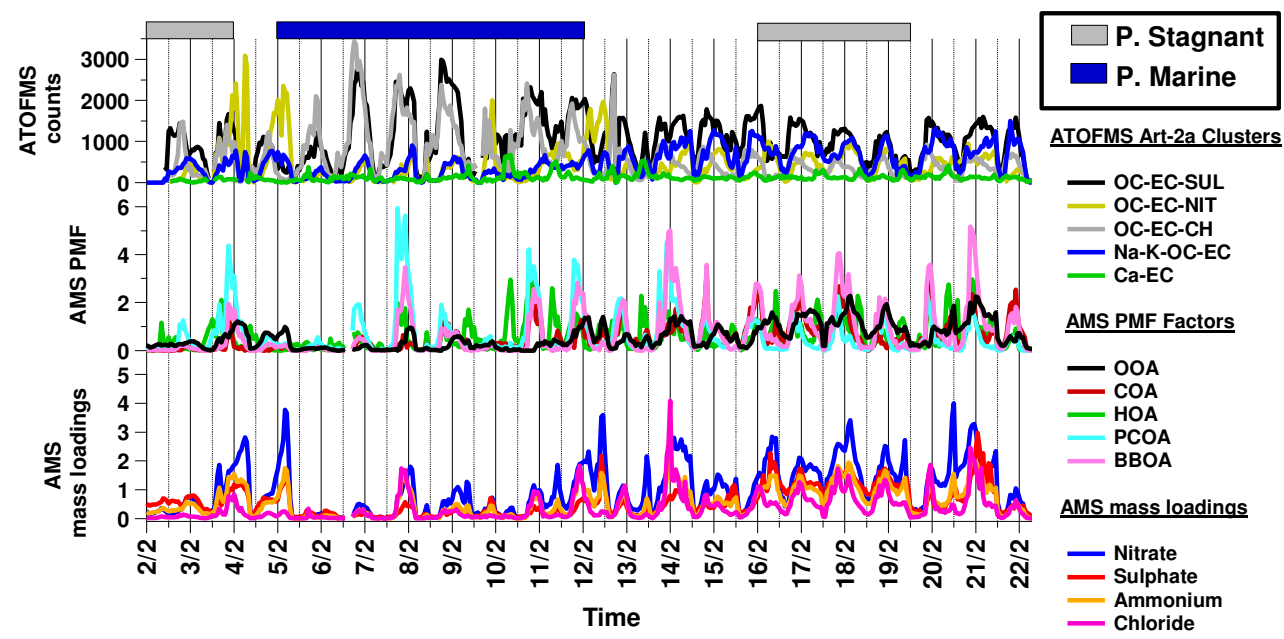

Fig. 3. ATOFMS (counts/hour) and AMS $\left(\mu \mathrm{g} \mathrm{m}^{-3}\right)$ time series.

$\mathrm{C}_{n}^{+}$), peaks at $\mathrm{m} / z 37$ and $\mathrm{m} / \mathrm{z} 55$ are often identified as key features of ATOFMS positive ion mass spectra (Dall'Osto and Harrison, 2006, 2012). The ATOFMS dataset was also queried (threshold value absolute peak area higher than 50) for signals at $\mathrm{m} / \mathrm{z} 213$, due to another common ATOFMS biomass marker $\left[\mathrm{K}_{3} \mathrm{SO}_{4}\right]^{+}$(Guazzotti et al., 2003), but not many single particle mass spectra were found containing this ion peak $(<0.1 \%)$. However, a number of particles were found containing peaks at $\mathrm{m} / \mathrm{z} 113(1 \%), \mathrm{m} / \mathrm{z}, 37(11 \%)$ and $\mathrm{m} / z 55(7 \%)$. Table S2 shows the correlations of these three key peaks $(\mathrm{m} / \mathrm{z}, 37, \mathrm{~m} / \mathrm{z} 55$ and $\mathrm{m} / \mathrm{z}, 113)$ associated with the five main organic ATOFMS particle types. Interestingly, these three peaks do not appear to correlate with traffic emissions (Ca-EC) or with nitrate-rich secondary organic particle types (OC-EC-NIT and Na-K-OC-NIT). In contrast, cluster OC-EC-CH seems more correlated with potassium chloride ion markers, whilst OC-EC-SUL is more associated with strong hydrocarbon-like species at $\mathrm{m} / \mathrm{z} 37$ and $\mathrm{m} / \mathrm{z}, 55$.

The temporal nature of the OC-EC-CH particle type suggests a combustion source. Additionally, the strongest correlation with biomass indicators $\left(\mathrm{m} / z, 113,\left[\mathrm{~K}_{2} \mathrm{Cl}\right]^{+}\right)$as well as the high similarity with the laboratory spectra obtained by Healy et al. (2010) also suggest a domestic peat combustion source. Cluster OC-EC-SUL shows a similarity to ATOFMS mass spectra obtained from burning coal, but the mass spectra do not contain unique marker ions and thus could also be assigned to other sources, possibly including fresh and aged different types of domestic combustion particles. Based on their temporal nature and comparison with the standard spectra reported in the literature, we assign the particles types OC-EC-CH and OC-EC-SUL to domestic fuel combustion sources, with the former being more associated with peat combustion. These particle types contributed up to $60.4 \%$ of the total particles classified, pointing to domestic fuel combustion as the major aerosol source in this study.

\subsection{HR-ToF-AMS}

\subsubsection{Aerosol mass loading and basic analysis}

The AMS CE used was 0.5 (Middlebrook et al., 2012). An inter-comparison of chemical species measured by the AMS and those derived from other techniques gave very good correlations with $R^{2}$ between 0.78 and 0.96 (Fig. S4) and quantitative agreements within $20 \%$. These comparisons are consistent with previous observations at other urban sites (Takegawa et al., 2005; Salcedo et al., 2006; Sun et al., 2010). Note that the 1:1 correlation of chloride suggests all of it is non-refractory (i.e. in the form of $\mathrm{NH}_{4} \mathrm{Cl}$ ). Overall, $62 \%$ of the aerosol mass loadings detected by the AMS is organic aerosol, with nitrate contributing $15 \%$, sulphate and ammonium $9 \%$, and chloride $5 \%$.

Within the organic fraction, $68 \%$ of the ion signal was due to the $\left[\mathrm{C}_{\mathrm{x}} \mathrm{H}_{y]}^{+}\right.$category, followed by $\left[\mathrm{C}_{\mathrm{x}} \mathrm{H}_{\mathrm{y}} \mathrm{O}_{1}\right]^{+}(27 \%)$, $\left[\mathrm{C}_{\mathrm{x}} \mathrm{H}_{\mathrm{y}} \mathrm{O}_{2}\right]^{+}(2.5 \%)$ and others $\left([\mathrm{OH}]^{+},\left[\mathrm{C}_{\mathrm{x}} \mathrm{H}_{\mathrm{y}} \mathrm{N}_{\mathrm{z}} \mathrm{O}_{p}\right]^{+}\right.$, $2.5 \%$ ). The average concentration found for organic aerosol was $4.3 \pm 2.6 \mu \mathrm{g} \mathrm{m}^{-3}$, nitrate was $1.0 \pm 0.7 \mu \mathrm{g} \mathrm{m}^{-3}$, sulphate was $0.6 \pm 0.4 \mu \mathrm{g} \mathrm{m}^{-3}$, ammonium was $0.6 \pm 0.4 \mu \mathrm{g} \mathrm{m}^{-3}$ and chloride was $0.2 \pm 0.3 \mu \mathrm{g} \mathrm{m}^{-3}$. The relatively high amount of chloride relative to other inorganic species is likely to be due to domestic combustion sources during wintertime (Lanz et al., 2010). The diurnal profile of the total aerosol mass measured by the AMS (Fig. 1d) shows a morning peak between 07:00 and 11:00, and an evening peak between 18:00 and 23:00. The organic fraction shows a similar pattern, but only the morning peak correlates with that of EC and NO (Fig. 1b), which is primarily due to local traffic emissions.

The evening peak in total aerosol mass is mostly due to domestic heating, as discussed in the next section. Nitrate showed lower concentrations in the afternoon between 13:00 and 17:00 (three-fold decrease relative to the daily hourly average), suggesting that gas-aerosol partitioning was mainly 


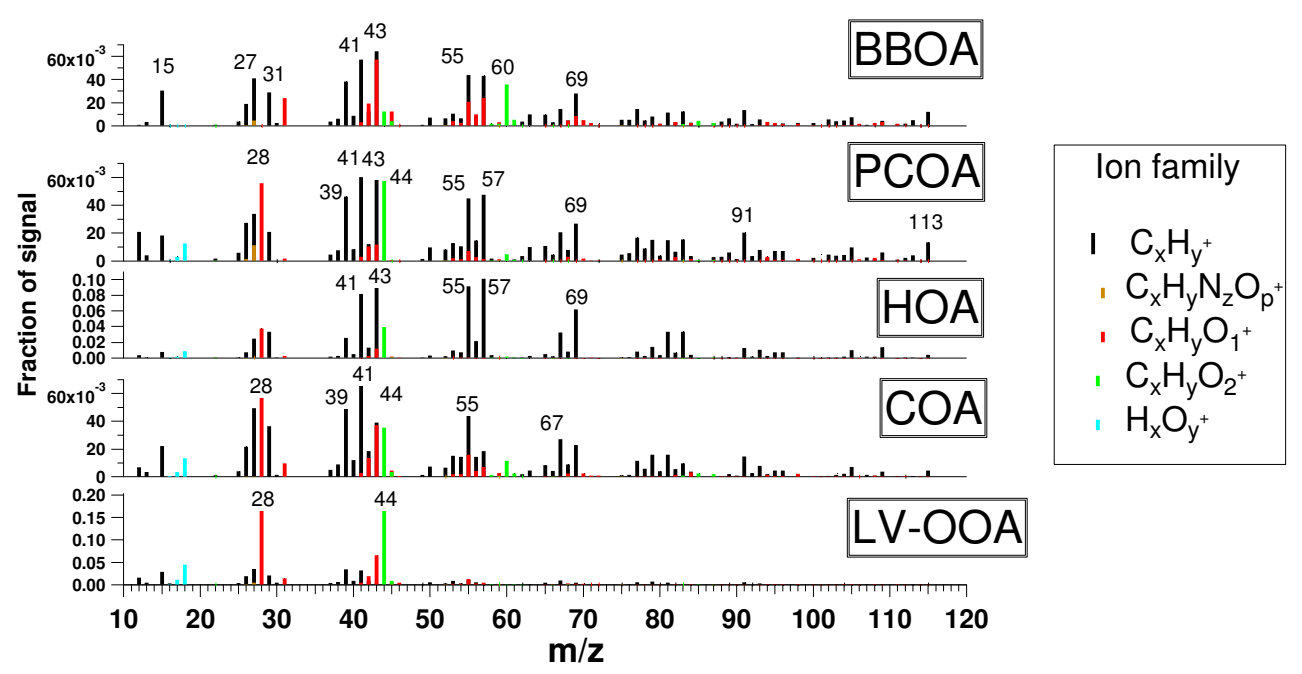

Fig. 4. Mass spectra of the five-factor PMF solution. The ion families of the different factors are shown in ion family box.

contributing to this signal. By contrast, sulphate showed the smallest diurnal variation of all the aerosol species. Ammonium also showed lower concentrations in the afternoon, with a diurnal profile in-between nitrate and sulphate (Fig. 1d), likely due to the combined contributions of $\left(\mathrm{NH}_{4}\right)_{2} \mathrm{SO}_{4}$, $\mathrm{NH}_{4} \mathrm{NO}_{3}$ and $\mathrm{NH}_{4} \mathrm{Cl}$. Chloride showed much lower concentrations in the afternoon, slowly increasing in concentration towards nighttime hours and peaking between 21:00 and 01:00 (Fig. 1d). This is due to a combination of the semi-volatile nature of $\mathrm{NH}_{4} \mathrm{Cl}$, the dynamics of the planetary boundary layer (PBL), and the increase in space heating emissions during nighttime (Alfarra et al., 2007).

\subsubsection{PMF analysis on AMS organic aerosol (OA) matrix}

The PMF analysis was performed for one to seven factors, and is described in detail in Supporting Information. It was found that the PMF solutions with factor numbers greater than five provided no new meaningful information and instead resulted in a splitting of the existing factors. The fivefactor solution was thus chosen as the optimal solution following a number of considerations, including correlations between the chosen AMS PMF solution and measurements taken using the other techniques.

\section{Hydrocarbon-like OA (HOA)}

The mass spectrum of HOA (Fig. 4) is dominated by organic fragments for saturated hydrocarbons $\left[\mathrm{C}_{n} \mathrm{H}_{2 n+1}\right]^{+}(\mathrm{m} / z 29$, $43,57,71)$ and unsaturated hydrocarbons $\left[\mathrm{C}_{n} \mathrm{H}_{2 n-1}\right]^{+}$ $(\mathrm{m} / \mathrm{z}, 27,41,55,69,83)$. Table S3 shows this factor possesses the strongest correlations among all factors with hydrocarbon peaks at $\mathrm{m} / z, 33\left(\left[\mathrm{C}_{3} \mathrm{H}_{7}\right]^{+}\right), \mathrm{m} / z 55\left(\left[\mathrm{C}_{4} \mathrm{H}_{7}\right]^{+}\right)$and $\mathrm{m} / z 57\left(\left[\mathrm{C}_{4} \mathrm{H}_{9}\right]^{+}\right)$. This factor is very similar to previously reported reference spectra of primary organic aerosol emitted
Table 3. Fraction of OA components to four ion categories for the five AMS factors.

\begin{tabular}{lcclll}
\hline \multicolumn{7}{c}{ AMS factor } \\
\hline Family & LV-OOA & COA & HOA & PCOA & BBOA \\
$\mathrm{C}_{\mathrm{x}} \mathrm{H}_{\mathrm{y}}$ & 0.02 & 0.71 & 0.87 & 0.78 & 0.68 \\
$\mathrm{C}_{\mathrm{x}} \mathrm{H}_{\mathrm{y}} \mathrm{O}_{1}$ & 0.56 & 0.25 & 0.10 & 0.18 & 0.24 \\
$\mathrm{C}_{\mathrm{x}} \mathrm{H}_{\mathrm{y}} \mathrm{O}_{2}$ & 0.35 & 0.03 & 0.00 & 0.01 & 0.06 \\
$\mathrm{HO}$ & 0.06 & 0.02 & 0.01 & 0.02 & 0.00 \\
$\mathrm{C}_{\mathrm{x}} \mathrm{H}_{\mathrm{y}} \mathrm{N}_{\mathrm{z}} \mathrm{O}_{\mathrm{p}}$ & 0.01 & 0.00 & 0.00 & 0.01 & 0.01 \\
\hline Total & 1.00 & 1.00 & 1.00 & 1.00 & 1.00 \\
\hline
\end{tabular}

from gasoline and diesel combustion sources (Canagaratna et al., 2004) and the spectra of HOA components determined at other sites (Aiken et al., 2009; Mohr et al., 2012; $R^{2}=0.8$ ). In addition, HOA was the only factor to correlate with traffic tracers such as $\mathrm{NO}_{\mathrm{x}}\left(R^{2}=0.39\right)$ and the unique ATOFMS traffic particle type Ca-EC $\left(R^{2}=0.35\right)$ (Table S5). However, it was not well correlated with EC $\left(R^{2}=0.32\right)$, implying additional sources of such species. Factor HOA presented a pronounced morning peak associated with traffic emissions (Fig. 1e). Table 3 illustrates that HOA has a dominant fraction of the organic mass spectra due to the $\left[\mathrm{C}_{\mathrm{x}} \mathrm{H}_{\mathrm{y}}\right]^{+}$category $(87 \%)$. HOA on average accounts for $20 \%$ of the total OA mass for the whole campaign (Fig. S6), and it contributes $26 \%$ of the $\left[\mathrm{C}_{\mathrm{x}} \mathrm{H}_{\mathrm{y}}\right]^{+}$total signal, making it the largest contributor.

\section{Low-volatility oxygenated OA (LV-OOA)}

The mass spectrum of LV-OOA (Fig. 4) illustrates a dominant peak at $m / z, 44\left(\left[\mathrm{CO}_{2}\right]^{+}\right)$, similar to the more oxidized LV-OOA component determined at other urban sites (Lanz et al., 2007; Ulbrich et al., 2009; $R^{2}=0.9$ ). It presents only 
$2 \%$ of the spectra associated with the $\left[\mathrm{C}_{\mathrm{x}} \mathrm{H}_{\mathrm{y}}\right]^{+}$ion category and $56 \%$ associated with $\left[\mathrm{C}_{\mathrm{x}} \mathrm{H}_{\mathrm{y}} \mathrm{O}_{1}\right]^{+}$(Table 3). Table $\mathrm{S} 3$ confirms the strongest correlation between this factor and $\mathrm{m} / z 44\left(\left[\mathrm{CO}_{2}\right]^{+}, R^{2}=0.64\right)$ and the weakest correlations with hydrocarbon $\left[\mathrm{C}_{\mathrm{x}} \mathrm{H}_{\mathrm{y}}\right]^{+}$species. This is the most oxygenated of all OA components and its mass spectra appear to represent an end product of OA oxidation (Jimenez et al., 2009). Our results, consistent with previous studies at various sites (Zhang et al., 2005; Lanz et al., 2007; Ulbrich et al., 2009; Sun et al., 2010), show very good correlations between LV-OOA and secondary inorganic species (Table S5): nitrate $\left(R^{2}=0.79\right)$, ammonium $\left(R^{2}=0.77\right)$ and sulphate $\left(R^{2}=0.75\right)$. Further support for this factor can be seen in the strongest correlation among all factors between LV-OOA and two ATOFMS organic-rich particle types internally mixed with nitrate (OC-EC-NIT and Na-K-OC-NIT) often considered as markers of secondary or aged aerosols (Dall'Osto and Harrison, 2012). The LV-OOA factor presents the least-marked diurnal variation (Fig. 1e) of all factors, peaking mainly during nighttime and likely driven mainly by boundary layer dynamics and possibly chemical processing. LV-OOA, on average, accounts for $18 \%$ of the total OA mass for the whole campaign, and it is the main contributor to the total signal of $\left[\mathrm{C}_{\mathrm{x}} \mathrm{H}_{\mathrm{y}} \mathrm{O}_{1}\right]^{+}(38 \%)$ and $\left[\mathrm{C}_{\mathrm{x}} \mathrm{H}_{\mathrm{y}} \mathrm{O}_{2}\right]^{+}(45 \%)$.

\section{Biomass burning OA (BBOA)}

The identification of a BBOA component is often driven by a prominent contribution of $m / z 60$ (Fig. 4), which is regarded as a tracer ion of biomass burning aerosols (Alfarra et al., 2007; Aiken et al., 2009) and not present in HOA. Highresolution analysis of the mass spectra obtained confirms that almost all the signal at this ion for ambient and source datasets is due to $\left[\mathrm{C}_{\mathrm{x}} \mathrm{H}_{\mathrm{y}} \mathrm{O}_{2}\right]^{+}$(Aiken et al., 2009; Mohr et al., 2009). Table $\mathrm{S} 3$ shows high correlations between BBOA and $\mathrm{m} / z 60\left(R^{2}=0.99\right)$ in addition to correlations at $\mathrm{m} / \mathrm{z} 55$ $\left(\left[\mathrm{C}_{3} \mathrm{H}_{3} \mathrm{O}\right]^{+}, R^{2}=0.95\right)$ and $m / z, 57\left(\left[\mathrm{C}_{3} \mathrm{H}_{5} \mathrm{O}\right]^{+}, R^{2}=0.99\right)$. It is important to note that the other ion peak usually associated with BBOA ( $\mathrm{m} / \mathrm{z}, 73$; Alfarra et al., 2007) was removed from this analysis due to excessively large residuals at this $m / z$.

Regarding the $\left[\mathrm{C}_{\mathrm{x}} \mathrm{H}_{\mathrm{y}}\right]^{+}$ion peaks, BBOA was found to correlate best with $m / z 29\left(\left[\mathrm{C}_{2} \mathrm{H}_{5}\right]^{+}\right), \mathrm{m} / z, 39\left(\left[\mathrm{C}_{3} \mathrm{H}_{3}\right]^{+}\right)$and $\mathrm{m} / z 41\left(\left[\mathrm{C}_{3} \mathrm{H}_{5}\right]^{+}\right)$(Table S3), while the peak at $\mathrm{m} / z 43$ is mainly composed of the oxidized component $\left[\mathrm{C}_{3} \mathrm{H}_{2} \mathrm{O}\right]^{+}$. In contrast to $\mathrm{HOA}$, the peaks at $\mathrm{m} / \mathrm{z} 55$ and $\mathrm{m} / \mathrm{z} 57$ contain both $\left[\mathrm{C}_{\mathrm{x}} \mathrm{H}_{\mathrm{y}}\right]^{+}\left(\left[\mathrm{C}_{4} \mathrm{H}_{7}\right]^{+}\right.$and $\left.\left[\mathrm{C}_{4} \mathrm{H}_{9}\right]^{+}\right)$and $\left[\mathrm{C}_{\mathrm{x}} \mathrm{H}_{\mathrm{y}} \mathrm{O}_{1}\right]^{+}$ $\left(\left[\mathrm{C}_{3} \mathrm{H}_{3} \mathrm{O}\right]^{+}\right.$and $\left[\mathrm{C}_{3} \mathrm{H}_{5} \mathrm{O}\right]^{+}$) families (Fig. 4).

When the time series of the BBOA factor is compared to other on-line and off-line measurements (Table S5), BBOA presents an excellent correlation with chloride $\left(R^{2}=0.87\right)$, and markers of biomass burning (levoglucosan, $R^{2}=0.80 ; \mathrm{K}$, $\left.R^{2}=0.65\right)$ supporting the assignment of the BBOA. The diurnal variation of this factor prevailing during night also confirms a domestic biomass burning source (Fig. 1e). BBOA was found to be the most abundant of all five AMS organic factors $(23 \%)$, with a mass spectrum dominated by $\left[\mathrm{C}_{\mathrm{x}} \mathrm{H}_{\mathrm{y}}\right]^{+}$ ions $(68 \%)$, followed by $\left[\mathrm{C}_{\mathrm{x}} \mathrm{H}_{\mathrm{y}} \mathrm{O}_{1}\right]^{+}(24 \%)$ and $\left[\mathrm{C}_{\mathrm{x}} \mathrm{H}_{\mathrm{y}} \mathrm{O}_{2}\right]^{+}$ $(6 \%)$. Overall, it was found to contribute to $20 \%, 24 \%$ and $14 \%$ to the total ion signal of $\left[\mathrm{C}_{\mathrm{x}} \mathrm{H}_{\mathrm{y}}\right]^{+},\left[\mathrm{C}_{\mathrm{x}} \mathrm{H}_{\mathrm{y}} \mathrm{O}_{1}\right]^{+}$and $\left[\mathrm{C}_{\mathrm{x}} \mathrm{H}_{\mathrm{y}} \mathrm{O}_{2}\right]^{+}$, respectively. In summary, AMS BBOA marker $(\mathrm{m} / \mathrm{z}, 60)$ is consistent with previous results which indicate that, although it is not a completely conserved tracer, at least a fraction of it persists during aging and it remains a good marker for BBOA (De Carlo et al., 2010). Further discussions on this AMS PMF factor can be found in Sect. 4.

\section{Peat and coal OA (PCOA)}

The PCOA factor shows a similar sequence of peaks to HOA at $m / z 41,43,55$ and 57, which suggests a combustion source (Fig. 4). However, while the $m / z, 43$ is mainly attributed to the $\left[\mathrm{C}_{\mathrm{x}} \mathrm{H}_{\mathrm{y}}\right]^{+}$family $(75 \%)$, peaks due to $\left[\mathrm{C}_{\mathrm{x}} \mathrm{H}_{\mathrm{y}} \mathrm{O}_{\mathrm{z}}\right]^{+}$are seen at $m / z 28$ and 44. Additionally, this factor presents an aromatic signature with strong peaks at $m / z 69,77,91$ and 115 (McLafferty et al., 1993). Table S3 shows that factor PCOA presents the strongest correlation among all clusters, with the ion peak at $m / z 39\left(\left[\mathrm{C}_{3} \mathrm{H}_{3}\right]^{+}\right)$. Table $\mathrm{S} 5$ shows good correlations with biomass markers (levoglucosan, $R^{2}=0.84$; $\mathrm{K}, R^{2}=0.50$ ). However, while the BBOA factor correlates more with chloride, the PCOA factor correlates more with bromide $\left(R^{2}=0.75\right.$, Table S5) and EC $\left(R^{2}=0.80\right.$, Table S5). Furthermore, factor PCOA shows weak although unique correlations with two specific ATOFMS particle types (OC-ECSUL $R^{2}=0.35$ and OC-EC-CH $R^{2}=0.29$, Table S5). The diurnal trends are slightly different to that observed for BBOA, peaking more during evening times (18:00-21:00) and then decreasing while BBOA concentrations continue to increase (Fig. 1e). This would imply that this factor is more dominant during earlier hours rather than during all night like BBOA. In summary, we attribute this factor to solid fuel combustion not associated with wood biomass burning. In order to further validate our domestic solid fuel source attribution, we compare the PCOA factor with the reference BBOA spectra (U1brich et al., 2012), and with AMS mass spectra obtained from the controlled experiments of peat and coal burning obtained in this study. Firstly, the standard AMS reference spectra for the BBOA factor (Ulbrich et al., 2012) was found to correlate only with BBOA $\left(R^{2}=0.7\right)$ and not with PCOA $\left(R^{2}=0.1\right)$. Secondly, the AMS spectra obtained during the combustion experiment (Fig. 5) were found to correlate only with ambient PCOA $\left(R^{2}=0.8\right.$ and $R^{2}=0.65$, respectively) and not with any of other four AMS-PMF factors. We therefore conclude that the ambient PCOA factor is associated mainly with peat burning and to a lesser degree with coal burning. It is important to note that Fig. 5 mainly shows that peat burning presents a spectrum more similar to this factor PCOA, with a peculiar strong aromatic signature at $m / z 69,91$ and 115 .

Peat is an accumulation of partially decayed vegetation matter with high water content. It is a mixture of plant parts at different decomposition stages (IEA, 2007; Tuohy et al., 


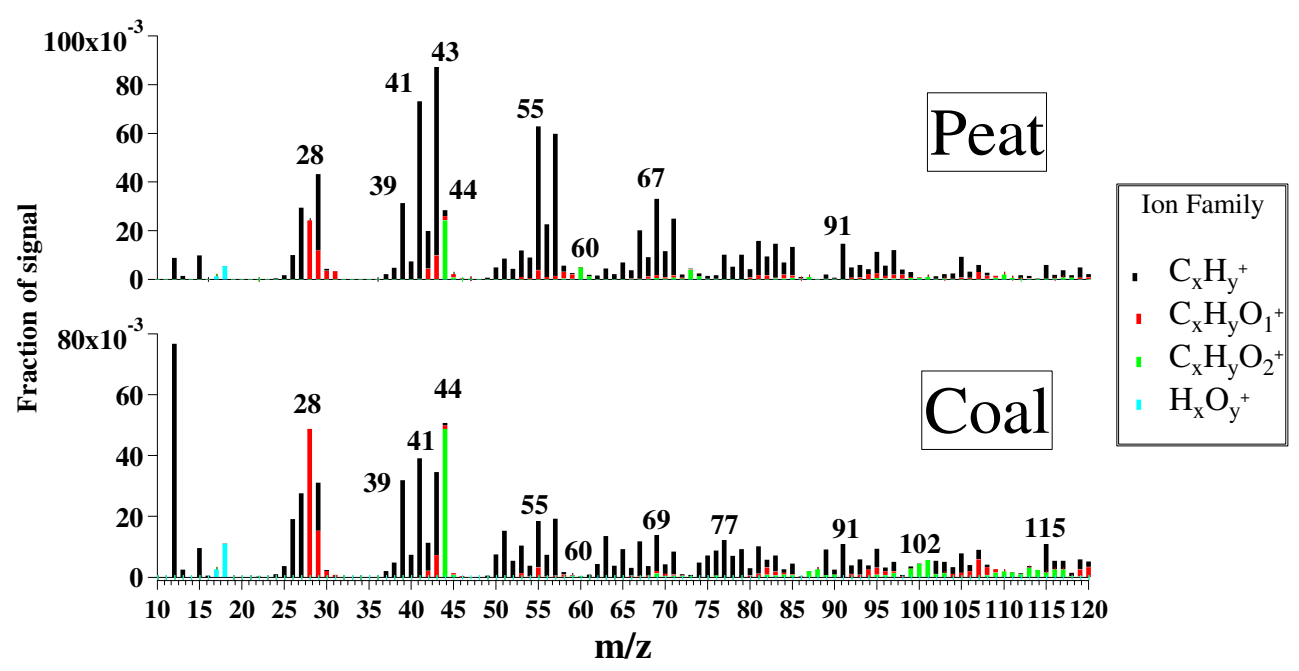

Fig. 5. Mass spectra of the peat and coal combustion laboratory experiment. The ion families of the different factors are shown in boxes.

2009). The transformation of peat organic matter by chemical, biochemical and biological decay leads to the formation of a number of chemical substances among which humic and fulvic acids and their salts, cellulose, lignite, bitumens, peptides, enzymes and fats are the most common (Szajdak et al., 2007). The burned components of peat consist mainly of hydrocarbons, biomarkers, and aromatic components, quite similar to burning of contemporary biomass (Simoneit et al., 2002). A general correlation between $\mathrm{Br}$ and soil organic peat matter content has been reported (Keppler and Biester, 2003; Biester et al., 2004), consistent with our study (Table S5). Zaccone et al. (2008) showed that more than $40 \%$ of the total $\mathrm{Br}$ present in peat is stably retained in humic acid molecules especially in the upper central part of the profile.

The appreciable signal seen at $m / z 44$ (Fig. 4), which implies a degree of oxygenation consistent with humic-like substances (HULIS) produced by biomass burning (Dinar et al., 2006, Weimer et al., 2008), along with the strong correlation between PCOA and bromide, make this cluster a unique one. In summary, this factor attributed to peat and coal combustion represents $21 \%$ of the total OA mass, and its mass spectra is dominated by $\left[\mathrm{C}_{\mathrm{x}} \mathrm{H}_{\mathrm{y}}\right]^{+}$peaks $(71 \%)$, followed by $\left[\mathrm{C}_{\mathrm{x}} \mathrm{H}_{\mathrm{y}} \mathrm{O}_{1}\right]^{+}(18 \%)$ and $\left[\mathrm{C}_{\mathrm{x}} \mathrm{H}_{\mathrm{y}} \mathrm{O}_{2}\right]^{+}(1 \%)$. Notably, this factor presented the highest amount (55\%) of total signal due to organonitrogen $\left[\mathrm{C}_{\mathrm{x}} \mathrm{H}_{\mathrm{y}} \mathrm{N}_{\mathrm{z}} \mathrm{O}_{p}\right]$ families, also making this factor distinct from the others.

\section{Cooking OA (COA)}

A factor thought to be COA (Fig. 4) presents the unique feature among all five factors of having $\mathrm{m} / \mathrm{z}$ of $41\left(\left[\mathrm{C}_{3} \mathrm{H}_{5}\right]^{+}\right)$ as a clear hydrocarbon peak. The second strongest $\left[\mathrm{C}_{\mathrm{x}} \mathrm{H}_{\mathrm{y}}\right]^{+}$ peak can be seen at $\mathrm{m} / \mathrm{z} 55\left(\left[\mathrm{C}_{4} \mathrm{H}_{7}\right]^{+}\right)$as well as $\mathrm{m} / \mathrm{z} 67$ $\left(\left[\mathrm{C}_{5} \mathrm{H}_{7}\right]^{+}\right)$. However, oxidized organic carbon peaks can also be seen. The $m / z 43$ is mainly composed of its oxidized frac- tion $\left(\left[\mathrm{C}_{3} \mathrm{H}_{2} \mathrm{O}\right]^{+}\right)$as well as the presence of a strong signal at $\mathrm{m} / \mathrm{z}, 44\left(\left[\mathrm{CO}_{2}\right]^{+}\right)$. Relative to the other factors, whilst there is an enhancement of signal for $\left[\mathrm{C}_{\mathrm{x}} \mathrm{H}_{\mathrm{y}}\right]^{+}$peaks at $m / z 55$ and $m / z 67$, other common $\left[\mathrm{C}_{\mathrm{x}} \mathrm{H}_{\mathrm{y}}\right]^{+}$peaks such as $m / z 57$ and $\mathrm{m} / \mathrm{z} 69$ are reduced (Fig. 4). Table $\mathrm{S} 3$ shows that factor COA presents the strongest correlations with $\mathrm{m} / z 41\left(\left[\mathrm{C}_{3} \mathrm{H}_{5}\right]^{+}\right)$ and $m / z, 55\left(\left[\mathrm{C}_{3} \mathrm{H}_{3} \mathrm{O}\right]^{+}\right)$, being two unique peaks attributed mainly to this factor. COA was found to contribute $18 \%$ to the total OA mass, and its mass spectra was mainly composed of $\left[\mathrm{C}_{\mathrm{x}} \mathrm{H}_{\mathrm{y}}\right]^{+}$peaks $(71 \%)$ followed by $\left[\mathrm{C}_{\mathrm{x}} \mathrm{H}_{\mathrm{y}} \mathrm{O}_{1}\right]^{+}(25 \%)$ and $\left[\mathrm{C}_{\mathrm{x}} \mathrm{H}_{\mathrm{y}} \mathrm{O}_{1}\right]^{+}(3 \%)$. Several studies associate this factor with cooking emissions. The first to report unit mass resolution (UMR) AMS factors featuring peaks at $m / z 41$ and $\mathrm{m} / \mathrm{z} 55$ was Lanz et al. (2007), who attributed it to charbroiling and food cooking. However, Mohr et al. (2009) pointed out that motor vehicles, plastic burning and meat cooking are very likely to be retrieved as a single component in PMF analysis of AMS data due to the similarity of their UMR spectra. A possibility for the amalgamation of HOA and COA was also discussed by $\mathrm{He}$ et al. (2011), if trafficrelated HOA and COA were temporally correlated at the sampling site of this campaign. Recent HR-ToF-AMS analysis of cooking and biomass emissions show high similarity, with $m / z 60$ more significantly emitted from biomass burning but also with detectable signals in cooking emissions. The mass spectrum of the COA factor is characterized by most prominent ions of $\mathrm{m} / \mathrm{z} 41$ and $\mathrm{m} / \mathrm{z} 55$, which indicates the presence of unsaturated organic compounds (e.g. unsaturated fatty acids) and is well consistent with the spectra measured for primary Chinese cooking emissions (He et al., 2010). Table S5 does not show any clear correlation with any collocated measurements for this COA factor. The diurnal variation shows a peak between 10:00 and 12:00 and then during evening times (Fig. 1e). However, the evening peak does not seem to decrease after evening time meals (19:00-21:00). We 
therefore cannot associate this factor only with cooking activities, and further discussion is provided in Sect. 4.

\section{Discussion}

\subsection{Aerosol mixing state and single particle analysis}

The results obtained by the ATOFMS show that the majority of the particles are internally mixed with both EC and OC. Additionally, two ATOFMS particle types distributed in the accumulation mode were found internally mixed with nitrate and organic species (OC-EC-NIT and Na-K-OC-EC) and are associated with secondary aerosol. In contrast, two main particle types were found rich in sulphate (OC-EC-SUL) and hydrocarbon-like species (OC-EC-CH) and were attributed to space heating combustion sources. Finally, a specific tracer for traffic combustion particles (internal mixture of $\mathrm{Ca}$ and EC) was found (Spencer et al., 2006; Drewnick et al., 2008; Dall'Osto et al., 2009).

During this field campaign we were able to successfully detect four spikes of PM which were responsible for raising the $\mathrm{PM}_{2.5}$ mass concentration at the port site to levels higher than those recorded in the city (Figs. S2, 3). These spikes coincided with increases in counts for the ATOFMS particle types Ca-dust and EC-POS and are attributed to localized emissions. $\mathrm{NaCl}$ was found to be a good tracer for separating different air mass types when air mass back trajectories were not entirely clear. The other ATOFMS particle types found were rich in vanadium, and associated with shipping emissions as discussed in the next section.

\subsection{Aerosol source apportionment with tandem AMS-ATOFMS}

\subsubsection{Traffic and shipping emissions}

We found specific markers for traffic emissions such as NO, AMS HOA and the ATOFMS particle type Ca-EC peculiar for this aerosol source.

As regards ship emissions, they represent one of the leastregulated forms of anthropogenic pollution due in large part to the challenges involved in establishing international policies. Field observations have confirmed that ships produce significant amounts of soot, vanadium, nickel, and sulfate (Eatough et al., 1984; Xie et al., 2006; Pattanaik et al., 2007). Ships typically burn residual fuel oil, which produces higher concentrations of heavy metals and soot than distillate fuels such as gasoline and diesel. ATOFMS studies often report a very specific particle type containing vanadium $\left(\mathrm{m} / z 51[\mathrm{~V}]^{+}\right.$ and $\mathrm{m} / \mathrm{z} 67$ [VO] $^{+}$) (Pastor et al., 2003; Dall'Osto and Harrison, 2006; Healy et al., 2009). Recent field measurements also reported that single particles containing organic carbon, vanadium, and sulfate (OC-V-sulfate) resulted from residual fuel combustion (i.e. bunker fuel), whereas high quantities of fresh soot particles represented distinct markers for plumes from distillate fuel combustion (i.e. diesel fuel) from ships as well as trucks in the port area (Ault et al., 2009, 2010).

During this field campaign the Port of Cork recorded 49 ship berthings, three of which were close enough to our monitoring site as their emissions were detected by the ATOFMS as being rich V-K-SUL particle types. Furthermore, it is important to note that a second type of V-rich particle was detected (V-NIT), showing that aged V-rich particles are enriched in nitrate. The AMS did not see a specific OA factor for ship emissions, but an enhancement of HOA was seen during fresh ship emissions spikes, as discussed in previous studies (Murphy et al., 2009; Lu et al., 2006). Several studies (e.g. Lack et al., 2009) have noted the increase in sulphate emissions associated with shipping emissions. During our study, we did not detect any increase in sulphate aerosol mass during the ship berthing, although elevated $\mathrm{SO}_{2}$ concentrations (hourly values of $3-6 \mu \mathrm{g} \mathrm{m}^{-3}$ ) were recorded.

\subsubsection{Domestic solid fuel combustion}

This AMS-ATOFMS study suggests that during wintertime domestic solid fuel combustion is the major source of OA in Cork. Such high OA concentrations are usually recorded in Alpine valleys in winter, attributed mostly to primary wood burning emissions (26-49\% of OA, Lanz et al., 2010). In small domestic combustion installations a wide variety of fuels are used and several combustion technologies are applied. The majority of domestic heating in Ireland relies on electricity, oil and natural gas, but coal is still commonly used as a solid fuel, along with peat, peat briquettes and, to a lesser extent, wood (IEA, 2007; COFORD, 2003). There is a ban on the use of bituminous coal in Cork city and other urban areas in Ireland, and smokeless coal is used instead. However, bituminous coal is still widely used in areas not included in the ban. The emissions from combustion of solid fuel strongly depend on the fuel, combustion technologies as well as on operational practices and maintenance. Table 4 shows the emission factors from the CEPMEIP database (TNO, 2001), showing very high emission estimates for particulate matter for wood, peat and briquettes. Our results suggest that despite the fact that wood and peat are minor sources of fuel for domestic heating (COFORD, 2003), their poor combustion efficiencies are responsible for high PM emissions.

Laboratory experiments of peat burning also reported higher emission factors of total fine particles in comparison to other biofuels. Very high emissions factors of $n$-alkanes and n-alkenes are observed from peat (Iinuma et al., 2007), along with furan-related compounds (Olsson et al., 2006) and aromatic volatile organic compounds (Blake at al., 2009). Finally, given the fact that peat contains elevated quantities of humic acid and bromide as a raw material, its combustion can potentially lead to dioxin formation, thus potentially affecting human health (Sinkkonen et al., 1995). 
Table 4. Emission factors from the CEPMEIP database (TNO, 2001).

\begin{tabular}{llll}
\hline Source & $\begin{array}{l}\text { Emission factor } \\
\mathrm{kg} \mathrm{PM}_{2.5} \mathrm{TJ}^{-1}\end{array}$ & $\begin{array}{l}\text { Net calorific value } \\
\mathrm{MJ} \mathrm{kg}^{-1}\end{array}$ & $\mathrm{KJ} \mathrm{m}^{-3}$ \\
\hline Bituminous coal & 30 & 27.84 & \\
Sod peat & 60 & 13.1 & \\
Briquettes & 60 & 18.55 & \\
Petroleum coke & 30 & 32.1 & \\
Fuel oil & 40 & 41.24 & \\
Gas oil & 5 & 43.31 & 39334 \\
Kerosene & 5 & 44.2 & \\
LPG & 0.2 & 47.16 & \\
Natural gas & 0.2 & & \\
Biomass (wood) & 270 & $\sim 16.00$ & \\
\hline
\end{tabular}

\subsubsection{Cooking organic aerosol}

The UMR ions of $\mathrm{m} / \mathrm{z}, 43, \mathrm{~m} / \mathrm{z}, 44, \mathrm{~m} / \mathrm{z}$ 57, and $\mathrm{m} / \mathrm{z}, 60$ have been used as tracers in MS of total OA, LV-OOA, HOA, and BBOA, respectively, because they typically correlate well with these OA components in statistical analysis of ambient datasets (Zhang et al., 2005; Alfarra et al., 2007). Recent studies suggest $m / z 41\left(\left[\mathrm{C}_{3} \mathrm{H}_{5}\right]^{+}\right)$and $m / z .55\left(\left[\mathrm{C}_{4} \mathrm{H}_{7}\right]^{+}\right.$and $\left[\mathrm{C}_{3} \mathrm{H}_{3} \mathrm{O}\right]^{+}$) are peaks due to COA although the UMR ion of $\mathrm{m} / \mathrm{z} 60$, typically used as the tracer for biomass burning, is also observed for cooking aerosol (Allan et al., 2010; He et al., 2010). As a result, there is increasing evidence showing that peaks at $\mathrm{m} / \mathrm{z}, 41,55$ and 60 may be distributed over a number of OA components, whereas the HOA and LV-OOA factors seem to be more well defined. Table S3 shows the correlation between the five factors and a number of selected peaks. COA and BBOA factors show similar patterns, both in $\mathrm{CH}$ and $\mathrm{CHO}$ ion families, although the specific peaks of $\left[\mathrm{C}_{2} \mathrm{H}_{4} \mathrm{O}_{2}\right]^{+}\left(\mathrm{m} / \mathrm{z}, 60, R^{2}=0.99\right)$ and $\left[\mathrm{C}_{3} \mathrm{H}_{5} \mathrm{O}\right]^{+}(\mathrm{m} / \mathrm{z}, 57$, $\left.R^{2}=0.99\right)$ are more specific to BBOA.

Recent measurements attribute a major part of primary OA to cooking activities: $16 \%$ in New York (Sun et al., 2010), $25 \%$ in London (Allan et al., 2010), $16 \%$ in Manchester (Allan et al., 2010), $24 \%$ in Beijing (Huang et al., 2010) and $17 \%$ in Barcelona (Mohr et al., 2012). The mass spectrum obtained in this study was found to be similar to other COA spectra $\left(R^{2}=0.82\right.$ in Mohr et al., 2012, and $R^{2}=0.71$ in Allan et al., 2010), pointing to cooking activities as the main source of this type of OA. Following the study of Mohr et al. (2012), COA was estimated from $\mathrm{m} / \mathrm{z}$ 55. Good agreement was found between COA obtained from the PMF presented in this study and the estimated one $\left(\mathrm{COA}_{\text {(estimated) }}=0.6 \mathrm{COA}_{\text {(this study })} ; R^{2}=0.84\right)$ although the correlation was better during daytime (10-15\% difference) than during nighttime (40-50\% difference).

However, the temporal trend of COA in our study does not reflect the expected cooking activities in Cork, suggesting that other sources and/or processes may be contributing to this factor. Previous COA diurnal cycles were related to peaks during midday (depending on lunch times of the different countries) and in the later evening. In Barcelona (Spain), Mohr et al. (2012) found that COA was shifted from expected lunch and dinner times, and the reason was attributed to sea breeze and nocturnal boundary layer height dynamics affecting the COA emissions. During our study (Fig. 1e) we find a small peak at 10:00-12:00, shortly after the morning rush hour and before typical Irish lunchtime activities (12:00-14:00). The large, broad nighttime peak is also not consistent with cooking activity. It is important to note these temporal trends can be seen not only in the PMF factors (Fig. 1e) but also in specific mass spectra peaks (Fig. S10, $\mathrm{m} / \mathrm{z} 55\left[\mathrm{C}_{3} \mathrm{H}_{3} \mathrm{O}\right]^{+}$and $\left.\mathrm{m} / z 57\left[\mathrm{C}_{3} \mathrm{H}_{5} \mathrm{O}\right]^{+}\right)$. The wind dependence for the COA factor differs from the other AMS PMF factors, showing a more southwesterly dependence (remote background region) rather than a localized urban source (Fig. S11). In summary, this OA factor is the least defined of all those identified in this study and is not solely attributable to cooking activities.

\subsection{Case study: Marine versus Stagnant time period}

Table 1 shows average values for different periods of the study (entire study, Period M. Period S., see also temporal trends in Fig. 3), as well as the ratio of S. versus M. average values (ratio $\mathrm{S} / \mathrm{M}$ ) of the measurements collected. As expected, high PM values are seen for Period S. as a consequence of low dispersion conditions. In particular, high concentrations of secondary species such as sulphate (ratio S / M 3.5), LV-OOA (ratio S / M 2.9) and ATOFMS aged V-rich particle types (ratio S/M 5.3) can be explained by accumulation of secondary aerosol over time in Period S. By contrast, more $\mathrm{NaCl}$ is observed as expected during Period M. (ratio S/M 0.3). Primary particles such as AMS HOA and ATOFMS Ca-EC present a S/M ratio close to one, because they are expected to be independent of air mass origin and due to local traffic/ship emissions. An unexpected result is the different temporality of the two primary domestic heating sources BBOA and PCOA. Whilst BBOA is higher during stagnant conditions, the AMS factor PCOA was found to present higher concentrations during marine conditions. Given the fact that these two aerosol domestic heating sources are likely to be highly correlated (similar emission time), it is possible that there is a chemical (aging) and/or physical process (evaporation, and consequent aerosol mass loss) affecting the lifetime of $\mathrm{BBOA}$ versus PCOA organic aerosols. The $\mathrm{O}_{3}$ and $\mathrm{NO}_{\mathrm{x}}$ concentrations were very different during the stagnant and marine periods (Table 1), which likely reflects different oxidizing conditions for the organic aerosol. Low $\mathrm{NO}_{\mathrm{x}}$ and high $\mathrm{O}_{3}$ concentrations in marine air masses indicate more-oxidized atmospheric conditions, which could be associated with the moreoxidized organics such as PCOA (having a high contribution from $m / z$ 44, see AMS spectra on Fig. 4). ATOFMS cluster OC-EC-CH (the ATOFMS particle type with the highest 
correlation with AMS PCOA, Table S5) was also found to be enhanced during marine conditions. When compared to marine periods, the stagnant periods exhibited the following meteorological differences: lower wind speed, warmer temperature, lower difference between day and nighttime temperature and $\mathrm{RH}$, higher RH during PCOA emission evening time periods (Fig. 2a). The enhancement of BBOA during stagnant conditions may be simply due to a higher regional contribution of this source, but the high $\mathrm{CH}$ content of PCOA may also indicate a higher volatility, hence reducing its lifetime during warm stagnant air masses. Overall, this study is in line with previous ones reporting different physical and chemical features of peat burning relative to other biofuels (Iinuma et al., 2007; Olsson 2006; Blake et al., 2009).

Figure S12 shows average size distributions and sizeresolved diurnal profiles for all species detected by the AMS (organics, nitrate, sulphate, ammonium, chloride) for the two different periods of the field study (stagnant and marine). As expected, an enhancement of secondary species can be seen in the accumulation mode during the stagnant period. Interestingly, during clean marine air masses, a finer mode of nitrate can be seen formed also during the daytime (Dall'Osto et al., 2009).

\subsection{Overall inter-comparison between ATOFMS ART-2a clusters and HR-ToF-AMS PMF factors}

Earlier work has demonstrated that the AMS-ATOFMS combination can give far greater insights into the chemical and physical processes of aerosols than either technique can do alone (Dall'Osto et al., 2009). The ATOFMS cannot provide direct quantitative aerosol mass loading concentrations, but its unique strength lies in the fact that it can monitor, in real time, variations in the single particle composition, usually giving a variety of particle types (about 10-20). By contrast, PMF analysis on the AMS organic matrix reveals precise quantitative features in the organic components of the aerosols although a lower number of aerosol types is usually obtained (about 3-5). The overall correlations between a few quantitative OA factors and several qualitative organic/inorganic ATOFMS particle types is complex and unfortunately at times have proven to be rather weak (Dall'Osto and Harrison, 2012). Nonetheless, the deployment of both instrument types yields insights into aerosol sources and behaviour not available from one type alone. This study confirms previous work (Dall'Osto et al., 2009) that shows a unique correlation between the AMS HOA factor and the ATOFMS Ca-EC particle type (See Table S5). Additionally, aged secondary organic aerosols detected by the AMS (LV-OOA) were also found to be fairly well correlated with secondary organic species detected with the ATOFMS (Na-K-OC-EC, $R^{2}=0.65$, Table S5). Weaker, although unique, correlations were also found with solid fuel combustion sources apportioned by AMS (factors BBOA and PCOA) and ATOFMS (types OC-EC-CH and OC-EC-SUL).
Unfortunately, the AMS COA factor was not found to correlate with any ATOFMS particle type, confirming previous studies in London (Dall'Osto and Harrison, 2012) showing the incapability of the ATOFMS to provide support for this aerosol source.

\section{Conclusions}

Two state-of-the-art on-line aerosol mass spectrometers (ATOFMS and HR-ToF-AMS) as well as a number of other off-line techniques were deployed for a three-week field measurement campaign in Cork, Ireland, during winter 2009. The ATOFMS revealed its unique capability to monitor in real time the variations in the single particle organic and inorganic composition. Unique particle types were attributed to sea spray, secondary nitrate, shipping and vehicular traffic emissions. Several organic particle types could be attributed to general solid fuel domestic combustion sources, although the source specificity of them could not be unambiguously assigned. PMF was applied to the HR-ToF-AMS organic matrix and a five-factor solution was found, supported both mathematically and with essential external correlations with parallel gaseous, aerosol off-line and ATOFMS measurements. AMS PMF factors HOA, LV-OOA, BBOA, PCOA and COA comprised $20 \%, 18 \%, 23 \%, 21 \%$ and $18 \%$ of the total non-refractory organic mass, respectively. The mass spectra of the COA factor was found to correlate well with previous cooking aerosol laboratory mass spectra, but during this study its diurnal trend was found to be different from expected cooking activities. Further studies will be required to unambiguously assign this factor correctly. The unique factor PCOA, herein presented for the first time, was found to correlate with bromine and a specific ATOFMS particle type, suggesting peat and/or combustion aerosol is enriched in bromine and both hydrocarbon-like and oxidized organic aerosol matter. Whilst wood burning BBOA seems to accumulate during stagnant atmospheric conditions, the PCOA factor exhibits different behaviour, perhaps suggesting that it undergoes chemical or physical processing. Despite the fact that wood, coal and peat are minor fuels used for domestic space heating in urban areas, their relatively low combustion efficiencies result in large contributions to organic aerosol mass and total $\mathrm{PM}_{1}$ aerosol mass $(44 \%$ and $28 \%$ of the total organic aerosols and non-refractory $\mathrm{PM}_{1}$, respectively). This study suggests that particulate emissions from residential wood, coal and peat burning have a major impact on the air quality of Cork. Although the AMS has been demonstrated to be an excellent tool for organic aerosol source apportionment, the use of different on-line aerosol instruments can provide more insight into aerosol sources and behaviour. 
Supplementary material related to this article is available online at: http://www.atmos-chem-phys.net/13/ 4997/2013/acp-13-4997-2013-supplement.pdf.

Acknowledgements. This work was funded by the Ireland Higher Education Authority Programme for Research in Third Level Institutes (PRTL1) - Cycle 5, and the Irish Environmental Protection Agency. NOAA HYSPLIT is acknowledged for providing air mass back trajectories. The authors would like to thank Stig Hellebust, Arnaud Allanic and Jenny Bell for assistance during the measurement campaign and the Port of Cork for providing access to the monitoring site. Manuel Dall'Osto would like to thank James Allan (NCAS Manchester), Sally Ng (GeorgiaTech), Manjula Canagaratna and Doug Worsnop (Aerodyne), and particularly Miss Donna Sueper (Aerodyne) for the help and discussions with AMS PMF analysis.

Edited by: N. Mihalopoulos

\section{References}

Aiken, A. C., Salcedo, D., Cubison, M. J., Huffman, J. A., DeCarlo, P. F., Ulbrich, I. M., Docherty, K. S., Sueper, D., Kimmel, J. R., Worsnop, D. R., Trimborn, A., Northway, M., Stone, E. A., Schauer, J. J., Volkamer, R. M., Fortner, E., de Foy, B., Wang, J., Laskin, A., Shutthanandan, V., Zheng, J., Zhang, R., Gaffney, J., Marley, N. A., Paredes-Miranda, G., Arnott, W. P., Molina, L. T., Sosa, G., and Jimenez, J. L.: Mexico City aerosol analysis during MILAGRO using high resolution aerosol mass spectrometry at the urban supersite (T0) - Part 1: Fine particle composition and organic source apportionment, Atmos. Chem. Phys., 9, 6633-6653, doi:10.5194/acp-9-6633-2009, 2009.

Alfarra, M. R., Prevot, A. S. H., Szidat, S., Sandradewi, J., Weimer, S., Lanz, V. A., Schreiber, D., Mohr, M., and Baltensperger, U.: Identification of the mass spectral signature of organic aerosols from wood burning emissions, Environ. Sci. Technol., 41, 57705777, doi:10.1021/Es062289b, 2007.

Allan, J. D., Williams, P. I., Morgan, W. T., Martin, C. L., Flynn, M. J., Lee, J., Nemitz, E., Phillips, G. J., Gallagher, M. W., and Coe, H.: Contributions from transport, solid fuel burning and cooking to primary organic aerosols in two UK cities, Atmos. Chem. Phys., 10, 647-668, doi:10.5194/acp-10-647-2010, 2010.

Ault, A. P., Moore, M. J., Furutani, H., and Prather, K. A.: Impact of Emissions from the Los Angeles Port Region on San Diego Air Quality during Regional Transport Events, Environ. Sci. Technol., 43, 3500-3506, doi:10.1021/es8018918, 2009.

Ault, A. P., Gaston, C. J., Wang, Y., Dominguez, G., Thiemens, M. H., and Prather, K. A.: Characterization of the Single Particle Mixing State of Individual Ship Plume Events Measured at the Port of Los Angeles, Environ. Sci. Technol., 44, 1954-1961, doi:10.1021/es902985h, 2010.

Biester, H., Keppler, F., Putschew, A., Cortizas, A. M., and Petri, M.: Halogen retention, organohalogens and the role of organic matter decomposition on halogen enrichment in two Chilean peat bogs, Environ. Sci. Technol., 38, 1984-1991, 2004.

Blake D, Hinwood, A. L., and Horwitz, P.: Peat fires and air quality: volatile organic compounds and particulates, Chemosphere, 76, 419-423, 2009.
Canagaratna, M. R., Jayne, J. T., Ghertner, D. A., Herndon, S., Shi, Q., Jimenez, J. L., Silva, P. J., Williams, P., Lanni, T., Drewnick, F., Demerjian, K. L., Kolb, C. E., and Worsnop, D. R.: Chase studies of particulate emissions from in-use New York city vehicles, Aerosol Sci. Tech., 38, 555-573, 2004.

Canagaratna, M. R., Jayne, J. T., Ghertner, D. A., Herndon, S., Shi, Q., Jimenez, J. L., Silva, P. J., Williams, P., Lanni, T., Drewnick, F., Demerjian, K. L., Kolb, C. E., and Worsnop, D. R.: Chemical and microphysical characterization of aerosols via Aerosol Mass Spectrometry, Mass Spectrom. Rev., 26, 185-222, 2007.

Ceburnis, D., Yin, J., Allen, A. G., Jennings, S. G., Harrison, R. M., Wright, E., Fitzpatrick, M., Healy, T., and Barry, E.: Local and regional air pollution in Ireland during an intensive aerosol measurement campaign, J. Environ. Monit., 8, 479-487, 2006.

COFORD strategic study: maximising the potential of wood use for energy generation in Ireland, http://www.seai.ie/Renewables/ Bioenergy/Maximising_the_potential_of_wood_energy,_Coford. pdf (last access: May 2013), 2003.

Dall'Osto, M. and Harrison, R. M.: Chemical characterisation of single airborne particles in Athens (Greece) by ATOFMS, Atmos. Environ., 40, 7614-7631, 2006.

Dall'Osto, M. and Harrison, R. M.: Urban organic aerosols measured by single particle mass spectrometry in the megacity of London, Atmos. Chem. Phys., 12, 4127-4142, doi:10.5194/acp12-4127-2012, 2012.

Dall'Osto, M., Beddows, D. C. S., Kinnersley, R. P., Harrison, R. M., Donovan, R. J., and Heal, M. R.: Characterization of individual airborne particles by using Aerosol Time-of-Flight Mass Spectrometry (ATOFMS) at Mace Head, Ireland, J. Geophys. Res., 109, D21302, doi:10.1029/2004/JD004747, 2004.

Dall'Osto, M., Harrison, R. M., Coe, H., Williams, P. I., and Allan, J. D.: Real time chemical characterization of local and regional nitrate aerosols, Atmos. Chem. Phys., 9, 3709-3720, doi:10.5194/acp-9-3709-2009, 2009.

DeCarlo, P. F., Kimmel, J. R., Trimborn, A., Northway, M. J., Jayne, J. T., Aiken, A. C., Gonin, M., Fuhrer, K., Horvath, T., Docherty, K. S., Worsnop, D. R., and Jimenez, J. L.: Field-Deployable, High-Resolution, Time-of-Flight Aerosol Mass Spectrometer, Anal. Chem., 78, 8281-8289, 2006.

DeCarlo, P. F., Ulbrich, I. M., Crounse, J., de Foy, B., Dunlea, E. J., Aiken, A. C., Knapp, D., Weinheimer, A. J., Campos, T., Wennberg, P. O., and Jimenez, J. L.: Investigation of the sources and processing of organic aerosol over the Central Mexican Plateau from aircraft measurements during MILAGRO, Atmos. Chem. Phys., 10, 5257-5280, doi:10.5194/acp-10-52572010, 2010.

Dinar, E., Mentel, T. F., and Rudich, Y.: The density of humic acids and humic like substances (HULIS) from fresh and aged wood burning and pollution aerosol particles, Atmos. Chem. Phys., 6, 5213-5224, doi:10.5194/acp-6-5213-2006, 2006.

Dockery, D. W., Pope, C. A., Xu, X. P., Spengler, J. D., Ware, J. H., Fay, M. E., Ferris, B. G., and Speizer, F. E.: An association between air-pollution and mortality in 6 United States cities, New Engl. J. Med., 329, 1753-1759, 1993.

Draxler, R. R. and Rolph, G. D.: HYSPLIT (Hybrid Single-Particle Lagrangian Integrated Trajectory) model v 4.9, NOAA Air Resource Laboratory, Silver Spring MD, available at: http://www. arl.noaa.gov/ready/hysplit4.html, 2003. 
Drewnick, F., Dall'Osto, M., and Harrison, R.: Characterization of aerosol particles from grass mowing by joint deployment of ToFAMS and ATOFMS instruments, Atmos. Environ. 42, 30063017, 2008.

Eatough, D. J., Eatough, N. L., Hill, M. W., Mangelson, N. F., and Hansen, L. D.: Identification of vanadate (VO2+) in particles from the flue lines of oil-fired power-plants, Environ. Sci. Technol., 18, 124-126, 1984.

EPA 2010: Air Quality in Ireland 2009. Key Indicators of Ambient Air Quality, Environmental Protection Agency, 2010.

Fenger, J.: Urban air quality, Atmos. Environ., 33, 4877-4900, 1999.

Gard, E., Mayer, J. E., Morrical, B. D., Dienes, T., Fergenson, D. P., and Prather K. A.: Real-time analysis of individual atmospheric aerosol particles: Design and performance of a portable ATOFMS, Anal. Chem., 69, 4083-4091, 1997.

Guazzotti, S. A., Suess, D. T., Coffee, K. R., Quinn, P. K., Bates, T. S., Wisthaler, A., Hansel, A., Ball, W. P., Dickerson, R. R., Neuß, C., Crutzen, P. J., and Prather, K. A.: Characterization of carbonaceous aerosols outflow from India and Arabia: Biomass/biofuel burning and fossil fuel combustion, J. Geophys. Res., 108, 4485, doi:10.1029/2002jd003277, 2003.

Harrison, R. M. and Yin, J. X.: Particulate matter in the atmosphere: which particle properties are important for its effects on health?, Sci. Total Environ., 249, 85-101, 2000.

He, L.-Y., Lin, Y., Huang, X.-F., Guo, S., Xue, L., Su, Q., Hu, M., Luan, S.-J., and Zhang, Y.-H.: Characterization of highresolution aerosol mass spectra of primary organic aerosol emissions from Chinese cooking and biomass burning, Atmos. Chem. Phys., 10, 11535-11543, doi:10.5194/acp-10-11535-2010, 2010.

He, L. Y., Huang, X. F., Xue, L., Hu, M., Lin, Y., Zheng, J., Zhang, R., and Zhang, Y. H. L: Submicron aerosol analysis and organic source apportionment in an urban atmosphere in Pearl River Delta of China using high-resolution aerosol mass spectrometry, J. Geophys. Res., 116, D12304, doi:10.1029/2010JD014566, 2011.

Healy, R. M., O’Connor, I. P., Hellebust, S., Allanic, A., Sodeau, J. R., and Wenger, J. C.: Characterisation of single particles from in-port ship emissions, Atmos. Environ., 43, 6408-6414, 2009.

Healy, R. M., Hellebust, S., Kourtchev, I., Allanic, A., O'Connor, I. P., Bell, J. M., Healy, D. A., Sodeau, J. R., and Wenger, J. C.: Source apportionment of $\mathrm{PM}_{2.5}$ in Cork Harbour, Ireland using a combination of single particle mass spectrometry and quantitative semi-continuous measurements, Atmos. Chem. Phys., 10, 9593-9613, doi:10.5194/acp-10-9593-2010, 2010.

Hellebust, S., Allanic, A., O'Connor, I. P., Wenger, J. C., and Sodeau, J. R.: The use of real-time monitoring data to evaluate major sources of airborne particulate matter, Atmos. Environ., 44, 1116-1125, 2010.

Huang, X.-F., He, L.-Y., Hu, M., Canagaratna, M. R., Sun, Y., Zhang, Q., Zhu, T., Xue, L., Zeng, L.-W., Liu, X.-G., Zhang, Y.-H., Jayne, J. T., Ng, N. L., and Worsnop, D. R.: Highly time-resolved chemical characterization of atmospheric submicron particles during 2008 Beijing Olympic Games using an Aerodyne High-Resolution Aerosol Mass Spectrometer, Atmos. Chem. Phys., 10, 8933-8945, doi:10.5194/acp-10-8933-2010, 2010.

IEA 2007: Published by the International Energy Agency, ISBN978-92-64-02772-5, 2007.
Iinuma, Y., Brüggemann, E., Gnauk, T., Müller, K., Andreae, M. O., Helas, G., Parmar, R., and Herrmann, H.: Source characterization of biomass burning particles: the combustion of European conifers, African hardwood, savanna grass, and German and Indonesian peat, J. Geophys. Res., 112, D08209, doi:10.1029/2006JD007120, 2007.

IEA: Energy balance for Ireland (2007). http://www.iea.org/stats/ balancetable.asp?COUNTRY_CODE=IE, last access: 4 June 2010.

Jayne, J. T., Leard, D. C., Zhang, X., Davidovits, P., Smith, K. A., Kolb, C. E., and Worsnop, D. R.: Development of an aerosol mass spectrometer for size and composition analysis of submicron particles, Aerosol Sci. Technol., 33, 49-70, 2000.

Jimenez, J. L., Canagaratna, M. R., Donahue, N. M., Prévôt, A. S. H., Zhang, Q., Kroll, J. H., DeCarlo, P. F., Allan, J. D., Coe, H., Ng, N. L., Aiken, A. C., Docherty, K. S., Ulbrich, I. M., Grieshop, A. P., Robinson, A. L., Duplissy, J., Smith, J. D., Wilson, K. R., Lanz, V. A., Hueglin, C., Sun, Y. L., Tian, J., Laaksonen, A., Raatikainen, T., Rautiainen, J., Vaattovaara, P., Ehn, M., Kulmala, M., Tomlinson, J. M., Collins, D. R., Cubison, M.J., Dunlea, E. J., Huffman, J. A., Onasch, T. B., Alfarra, M. R., Williams, P. I., Bower, K., Kondo, Y., Schneider, J., Drewnick, F., Borrmann, S., Weimer, S., Demerjian, K., Salcedo, D., Cottrell, L., Griffin, R., Takami, A., Miyoshi, T., Hatakeyama, S., Shimono, A., Sun, J. Y., Zhang, Y. M., Dzepina, K., Kimmel, J. R., Sueper, D., Jayne, J. T., Herndon, S. C., Trimborn, A. M., Williams, L. R., Wood, E. C., Middlebrook, A. M., Kolb, C. E., Baltensperger, U., and Worsnop, D. R.: Evolution of organic aerosols in the atmosphere, Science, 326, 1525-1529, 2009.

Kourtchev, I., Hellbust, S., Bell, J. M., O’Connor, I. P., Healy, R. M., Allanic, A., Healy, D., Wenger, J. C., and Sodeau, J. R.: The use of polar organic compounds to estimate the contribution of domestic solid fuel combustion and biogenic sources to ambient levels of organic and $\mathrm{PM}_{2.5}$ in Cork Harbour, Sci. Total Environ., 409, 2143-2155, 2011.

Lack, D. A., Corbett, J. J., Onasch, T., Lerner, B., Massoli, P., Quinn, P. K., Bates, T. S., Covert, D. S., Coffman, D., Sierau, B., Herndon, S., Allan, J., Baynard, T., Lovejoy, E., Ravishankara, A. R., and Williams, E.: Particulate emissions from commercial shipping: Chemical, physical, and optical properties, J. Geophys. Res., 114, D00F04, doi:10.1029/2008JD011300, 2009.

Lanz, V. A., Alfarra, M. R., Baltensperger, U., Buchmann, B., Hueglin, C., and Prevot, A. S. H.: Source apportionment of submicron organic aerosols at an urban site by factor analytical modelling of aerosol mass spectra, Atmos. Chem. Phys., 7, 15031522, doi:10.5194/acp-7-1503-2007, 2007.

Lanz, V. A., Prévôt, A. S. H., Alfarra, M. R., Weimer, S., Mohr, C., DeCarlo, P. F., Gianini, M. F. D., Hueglin, C., Schneider, J., Favez, O., D’Anna, B., George, C., and Baltensperger, U.: Characterization of aerosol chemical composition with aerosol mass spectrometry in Central Europe: an overview, Atmos. Chem. Phys., 10, 10453-10471, doi:10.5194/acp-10-10453-2010, 2010.

Lu, G., Brook, J. R., Alfarra, M. R., Anlauf, K., Leaitch, W. R., Sharma, S., Wang, D., Worsnop, D. R., Phinney, L.: Identification and characterization of inland ship plumes over Vancouver, BC, Atmos. Environ. 40, 2767-2782, 2006.

McLafferty, F. W.: Interpretation of Mass Spectra, third ed., 303 pp., 1993. 
Middlebrook, A. M., Bahreini, R., Jimenez, J. L., and Canagaratna, M. R.: Evaluation of Composition-Dependent Collection Efficiencies for the Aerodyne Aerosol Mass Spectrometer using Field Data, Aerosol Sci. Technol., 46, 258-271, doi:10.1080/02786826.2011.620041, 2012.

Moffet, R. C., de Foy, B., Molina, L. T., Molina, M. J., and Prather, K. A.: Measurement of ambient aerosols in northern Mexico City by single particle mass spectrometry, Atmos. Chem. Phys., 8, 4499-4516, doi:10.5194/acp-8-4499-2008, 2008.

Mohr, C., Huffman, J. A., Cubison, M. J., Aiken, A. C., Docherty, K. S., Kimmel, J. R., Ulbrich, I. M., Hannigan, M., and Jimenez, J. L.: Characterization of primary organic aerosol emissions from meat cooking, trash burning, and motor vehicles with HighResolution Aerosol Mass Spectrometry and comparison with ambient and chamber observations, Environ. Sci. Technol., 43, 2443-2449, doi:10.1021/es8011518, 2009.

Mohr, C., DeCarlo, P. F., Heringa, M. F., Chirico, R., Slowik, J. G., Richter, R., Reche, C., Alastuey, A., Querol, X., Seco, R., Peñuelas, J., Jiménez, J. L., Crippa, M., Zimmermann, R., Baltensperger, U., and Prévôt, A. S. H.: Identification and quantification of organic aerosol from cooking and other sources in Barcelona using aerosol mass spectrometer data, Atmos. Chem. Phys., 12, 1649-1665, doi:10.5194/acp-12-1649-2012, 2012.

Murphy, S. M., Agrawal, H., Sorooshian, A., Padro, L. T., Gates, H., Hersey, S., Welch, W. A., Jung, H., Miller, J. W., Cocker, D. R., Nenes, A., Jonsson, H., Flagan, R. C., and Seinfeld, J. H.: Comprehensive Simultaneous Shipboard and Airborne Characterization of Exhaust from a Modern Container Ship at Sea, Environ. Sci. Tech., 43, 4626-4640, 2009.

Olsson, M.: Wheat Straw and Peat for Fuel pellets - organic Compounds from Combustion, Biomass Bioenerg., 30, 555-564, 2006.

Paatero, P. and Tapper, U.: Positive matrix factorization: A nonnegative factor model with optimal utilization of error estimates of data values, Environmetrics, 5, 111-126, 1994.

Pastor, S. H., Allen, J. O., Hughes, L. S., Bhave, P., Cass, G. R., and Prather, K. A.: Ambient single particle analysis in Riverside, California by aerosol time-of-flight mass spectrometry during the SCOS97-NARSTO, Atmos. Environ., 37, S239-S258, 2003.

Pattanaik, S., Huggins, F. E., Huffman, G. P., Linak, W. P., and Miller, C. A.: XAFS studies of nickel and sulfur speciation in residual oil fly-ash particulate matters (ROFA PM), Environ. Sci. Technol., 41, 1104-1110, 2007.

Pio, C. A., Legrand, M., Oliveira, T., Afonso, J., Santos, C.,Caseiro, A., Fialho, P., Barata, F., Puxbaum, H., Sanchez-Ochoa, A., Kasper-Giebl, A., Gelencser, A., Preunkert, S., and Schock, M.: Climatology of aerosol composition (organic versus inorganic) at nonurban sites on a west-east transect across europe, J. Geophys. Res.-Atmos., 112, D23S02, doi:10.1029/2006JD008038, 2007.

Pope, C. A. and Dockery, D. W.: Health effects of fine particulate air pollution: Lines that connect, J. Air Waste Manage., 56, 709_ $742,2006$.

Putaud, J.-P., Van Dingenen, R., Alastuey, A., Bauer, H., Birmili, W., Cyrys, J., Flentje, H., Fuzzi, S., Gehrig, R., Hansson, H. C., Harrison, R. M., Herrmann, H., Hitzenberger, R., Huglin, C., Jones, A. M., Kasper-Giebl, A., Kiss, G., Kousa, A., Kuhlbusch,T. A. J., Loschau, G., Maenhaut, W., Molnar, A., Moreno, T., Pekkanen, J., Perrino, C., Pitz, M., Puxbaum, H., Querol, X., Rodriguez, S., Salma, I., Schwarz, J., Smolik,
J., Schneider, J., Spindler, G., ten Brink, H., Tursic, J., Viana, M., Wiedensohler, A., and Raes, F.: A European Aerosol Phenomenology - 3: Physical and chemical characteristics of particulate matter from 60 rural, urban, and kerbside sites across Europe, Atmos. Environ., 44, 1308-1320, 2010.

Rimetz-Planchon, J., Perdrix, E., Sobanska, S., and Brémard, C.: $\mathrm{PM}_{10}$ air quality variations in an urbanized and industrialized harbor, Atmos. Environ., 42, 7274-7283, doi:10.1016/j.atmosenv.2008.07.005, 2008.

Salcedo, D., Onasch, T. B., Dzepina, K., Canagaratna, M. R., Zhang, Q., Huffman, J. A., DeCarlo, P. F., Jayne, J. T., Mortimer, P., Worsnop, D. R., Kolb, C. E., Johnson, K. S., Zuberi, B., Marr, L. C., Volkamer, R., Molina, L. T., Molina, M. J., Cardenas, B., Bernabé, R. M., Márquez, C., Gaffney, J. S., Marley, N. A., Laskin, A., Shutthanandan, V., Xie, Y., Brune, W., Lesher, R., Shirley, T., and Jimenez, J. L.: Characterization of ambient aerosols in Mexico City during the MCMA-2003 campaign with Aerosol Mass Spectrometry: results from the CENICA Supersite, Atmos. Chem. Phys., 6, 925-946, doi:10.5194/acp-6-925-2006, 2006.

Simoneit, B. R. T.: Biomass burning - a review of organic tracers for smoke from incomplete combustion, App. Geochem., 17, 129162, 2002.

Sinkkonen, S., Raitio, H., Paasivirta, J., Rantio, T., Lahtipera, M., and Makela, R.: Concentrations of persistent organochlorine compounds in spruce needles from western Finland, Chemosphere, 30, 1415-1422, 1995.

Song, X. H., Hopke, P. K., Fergenson, D. P., and Prather, K. A.: Classification of single particles analyzed by ATOFMS using an artificial neural network, ART-2A. Anal. Chem, 71, 860-865, 1999.

Spencer, M. T., Shields, L. G., Sodeman, D. A., Toner, S. M., and Prather, K. A.: Comparison of oil and fuel particle chemical signatures with particle emissions from heavy and light duty vehicles, Atmos. Environ., 40, 5224-5235, 2006.

Sun, J., Zhang, Q., Canagaratna, M. R., Zhang, Y., Ng, N. L., Sun, Y., Jayne, J. T., Zhang, X., Zhang, X., and Worsnop, D. R.: Highly time- and size-resolved characterization of submicron aerosol particles in Beijing using an Aerodyne Aerosol Mass Spectrometer, Atmos. Environ., 44, 131-140, 2010.

Szajdak, L., Brandyk, T., and Szatylowicz, J.: Chemical properties of different peat-moors soils from the Biebrza River Valley, Agr. Res., 5, 165-174, 2007.

Takegawa, N., Miyazaki, Y., Kondo, Y., Komazaki, Y., Miyakawa, T., Jimenez, J. L., Jayne, J. T., Worsnop, D. R., Allan, J. D., and Weber, R. J.: Characterization of an Aerodyne Aerosol Mass Spectrometer (AMS): Intercomparison with other aerosol Instruments, Aerosol Sci. Tech., 39, 760-770, 2005.

TNO 2001: TNO Institute of Environmental Sciences, Energy Research and Process Innovations: CEPMEIP Database, available at http://www.air.sk/tno/cepmeip/ (last access: November 2011), Apeldoorn 2001,.

Tuohy, A., Bazilian, M., Doherty, R., O'Gallachoir, B., and O'Malley, M.: Burning peat in Ireland: An electricity market dispatch perspective, Energ. Pol., 37, 3035-3042, 2009.

Ulbrich, I. M., Canagaratna, M. R., Zhang, Q., Worsnop, D. R., and Jimenez, J. L.: Interpretation of organic components from Positive Matrix Factorization of aerosol mass spectrometric data, Atmos. Chem. Phys., 9, 2891-2918, doi:10.5194/acp-9-2891-2009, 
2009.

Ulbrich, I. M., Lechner, M., and Jimenez, J. L.: AMS Spectral Database, available at: http://cires.colorado.edu/jimenez-group/ AMSsd/ (last access: March 2013), 2012.

Weimer, S., Alfarra, M. R., Schreiber, D., Mohr, M., Prevot, A. S. H., and Baltensperger, U.: Organic aerosol mass spectral signatures from wood-burning emissions: Influence of burning conditions and wood type, J. Geophys. Res.-Atmos., 113, D10304, doi:10.1029/2007jd009309, 2008.

WHO: Air Quality Guidelines Global Update. http://www.euro. who.int/__data/assets/pdf_file/0005/78638/E90038.pdf) (last access: March 2013), 2005.

Yin, J., Allen, A. G., Harrison, R. M., Jennings, S. G., Wright, E., Fitzpatrick, M., Healy, T., Barry, E., Ceburnis, D., and McCusker, D.: Major component composition of urban $\mathrm{PM}_{10}$ and $\mathrm{PM}_{2.5}$ in Ireland, Atmos. Res., 78, 149-165, doi:10.1016/j.atmosres.2005.03.006, 2005.
Xie, Z. Q., Sun, L. G., Blum, J. D., Huang, Y. Y., and He, W.: Summertime aerosol chemical components in the marine boundary layer of the Arctic Ocean, J. Geophys. Res. Atmos., 111, D10309, doi:10.1029/2005JD006253, 2006.

Zaccone, C., Cocozza, C., Shotyk, W., and Miano, T.: Humic acids role in $\mathrm{Br}$ accumulation along two ombrotrophic peat bog profiles, Geoderma, 146, 26-31, 2008.

Zhang, Q., Worsnop, D. R., Canagaratna, M. R., and Jimenez, J. L.: Hydrocarbon-like and oxygenated organic aerosols in Pittsburgh: insights into sources and processes of organic aerosols, Atmos. Chem. Phys., 5, 3289-3311, doi:10.5194/acp-5-32892005, 2005. 